\title{
Republic of Korea: Article IV Consultation-Staff Report; Public Information Notice on the Executive Board Discussion; and Statement by the Executive Director for the Republic of Korea
}

Under Article IV of the IMF's Articles of Agreement, the IMF holds bilateral discussions with members, usually every year. In the context of the Article IV consultation with the Republic of Korea, the following documents have been released and are included in this package:

- $\quad$ The staff report for the Article IV consultation, prepared by a staff team of the IMF, following discussions that ended on July 6, 2010, with the officials of the Republic of Korea on economic developments and policies. Based on information available at the time of these discussions, the staff report was completed on August 3, 2010. The views expressed in the staff report are those of the staff team and do not necessarily reflect the views of the Executive Board of the IMF.

- A Public Information Notice (PIN) summarizing the views of the Executive Board as expressed during its August 25, 2010 discussion of the staff report that concluded the Article IV consultation.

- $\quad$ A statement by the Executive Director for the Republic of Korea.

The document listed below has been or will be separately released.

Selected Issues Paper

The policy of publication of staff reports and other documents allows for the deletion of market-sensitive information.

\author{
Copies of this report are available to the public from \\ International Monetary Fund • Publication Services \\ $70019^{\text {th }}$ Street, N.W. • Washington, D.C. 20431 \\ Telephone: (202) 623-7430 • Telefax: (202) 623-7201 \\ E-mail: publications@imf.org Internet: http://www.imf.org
}

\section{International Monetary Fund \\ Washington, D.C.}




\section{Republic of Korea: Staff Report for the 2010 Article IV Consultation ${ }^{1}$}

Prepared by Staff Representatives for the 2010 Consultation with the Republic of Korea Approved by Mahmood Pradhan and Aasim Husain

\section{Key Issues and Recommendations:}

- Growth prospects: Growth is projected to recover to 6.1 percent in 2010 , led by fixed investment and restocking, and ease to $4 \frac{1}{2}$ percent next year. Downside risks relate to the global economic and financial outlook, including a further escalation of the turmoil in southern Europe and a worsening of geopolitical tensions in the Korean peninsula. These are balanced by the potentially faster rebound in domestic demand.

- Achieving a smooth transition to private sector-led growth: Given the significant fiscal withdrawal in 2010, the ongoing front-loading of spending will help smooth the transition to private sector-led growth. With the output gap closing rapidly and policy rates well below neutral, monetary accommodation should continue to be gradually withdrawn. If sovereign concerns in Europe result in adverse spillovers on Korea, an adjustment of macroeconomic policies may be called for.

- Enhancing macrofinancial policy frameworks: The authorities' are encouraged to provide details on the medium-term fiscal consolidation measures and further formalize the medium-term fiscal framework. The Bank of Korea (BOK) could allow asset prices to play a larger role in determining the appropriate monetary policy stance. Under current arrangements, there is also scope to formalize the coordination among agencies responsible for financial stability to better internalize macrofinancial linkages.

- Safeguarding financial stability: The authorities have taken pre-emptive measures to reduce vulnerabilities associated with wholesale funding and short-term external bank debt. Regulatory and supervisory frameworks may need to be tightened further, consistent with future global changes, to prevent regulatory arbitrage.

- Diversifying sources of growth: Policies should focus on strengthening the nontradables sector. This would sustain growth in the face of moderating export growth to advanced economies and mitigate vulnerabilities to external demand shocks. Measures should aim at restructuring the highly indebted small- and medium-sized enterprises (SMEs), increasing competition in services, and raising labor market flexibility.

${ }^{1}$ Discussions took place in Seoul from June 23-July 6, 2010. The staff team comprised Messrs. Lall (head), Eskesen and Zeng, and Ms. Karasulu (all APD). Approved by Mahmood Pradhan and Aasim Husain. 


\section{Contents}

I. Introduction 3

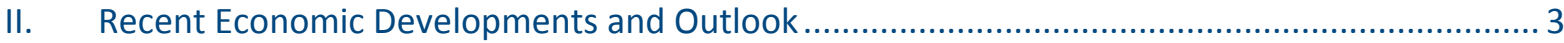

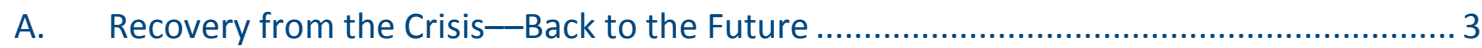

B. Outlook and Risks_-Ignition of the Private Engine of Growth ......................................... 7

III. Policy Theme \#1-Managing the Transition to Private-Led Growth ...................................... 9

IV Policy Theme \#2: Securing Economic Resilience and Sustainable Growth ............................. 13

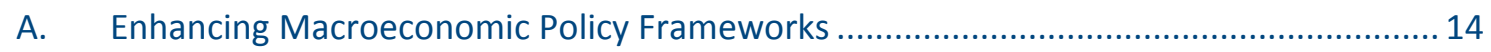

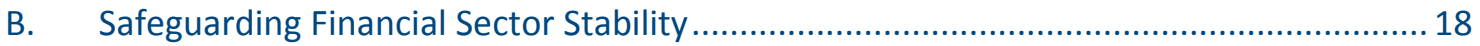

C. Product and Labor Market Policies_Diversifying the Sources of Growth...................... 20

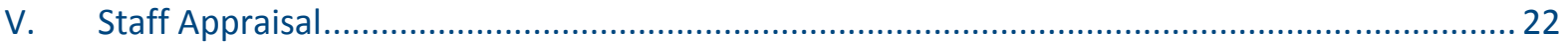

\section{Boxes}

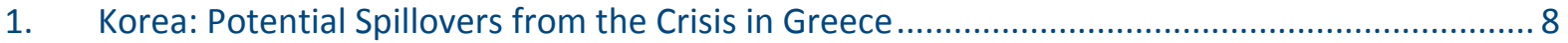

2. Time for Monetary Policy Normalization in Korea? ................................................................... 12

3. A Role for Asset Prices in Korea's Monetary Policy Framework? ............................................. 17

Figures

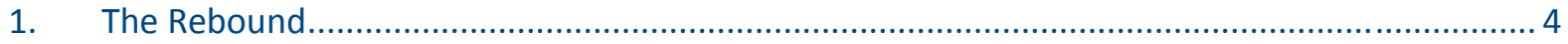

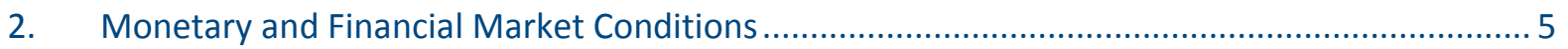

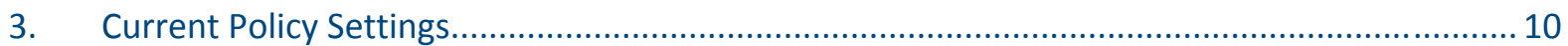

Tables

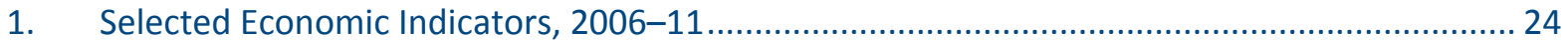

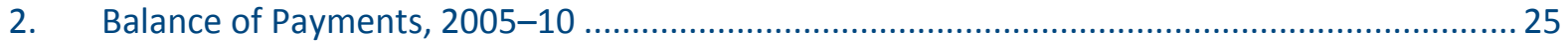

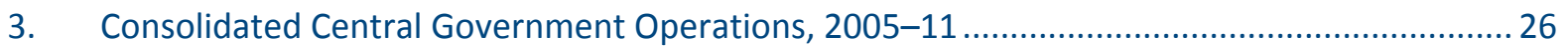

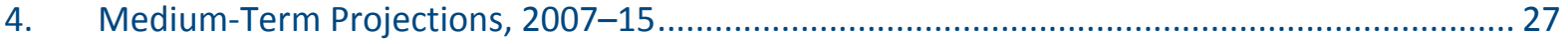

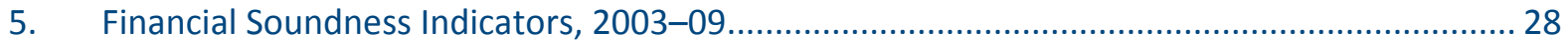

6. Indicators of Financial and External Vulnerability, 2005-10 ............................................... 29 


\section{INTRODUCTION}

1. The Korean economy has staged an impressive recovery over the past year. The "Great Recession" had a large impact on Korea's open economy through collapsing exports and massive capital outflows. The authorities responded with decisive policy measures to cushion the adverse spillovers to the Korean economy and financial system. This helped avoid a deeper slump and sowed the seeds for the subsequent strong rebound in activity.

2. It is now time to exit from supportive policies and design a strategy to sustain growth and enhance economic resilience over the medium term. Over the near term, the recovery is expected to firm, paving the way for the exit from supportive policies. Moreover, the "Great Recession" has informed the debate on the appropriate design of macroeconomic policy frameworks, the nature of macro-financial linkages, and ways to further strengthen supervisory and regulatory frameworks. It also underscored Korea's exposure to external shocks. With a robust recovery now underway, this is a good opportunity to reflect on the lessons from the recent crisis and formulate an appropriate medium-term policy strategy to sustain growth and bolster the economy's resilience to future shocks.

\section{RECENT ECONOMIC DEVELOPMENTS AND OUTLOOK}

\section{A. The Recovery from the Crisis-Back to the Future}

3. Growth has rebounded impressively since the recession in the second half of 2008 (Figure 1). Following the collapse in economic activity in the fourth quarter of 2008 (-16.8 percent q/q seasonally-adjusted annualized rate (SAAR)), the subsequent recovery has solidified with GDP growth averaging 7.4 percent ( $q / q$ SAAR) in the first half of 2010. Moreover, the recovery is increasingly being driven by private sector demand, in particular fixed investment and a slowdown in destocking. This rebound owes to a number of factors, including a proactive policy response and the normalization in global trade. Monetary policy rates were cut by 325 basis points between October 2008 and February 2009 and fiscal policy eased significantly (an estimated fiscal impulse of $2 \frac{1}{4}$ percent in 2009), against the backdrop of strong underlying public finances. Moreover,
Korea's export-dependent economy benefited greatly from the rapid rebound in international trade, partly led by the turning of the global inventory cycle, and the initial steep depreciation of the won. Finally, the healthy balance sheet positions of banks and large corporates made them resilient to the downturn.

4. Despite the recovery and strong capital inflows, inflation pressures and asset valuations remain contained (Figure 2).

- $\quad$ Consumer prices: There are no signs yet of inflation pressures and inflation expectations remain well anchored as reflected in consensus forecasts. However, both headline and core inflation have trended up in recent months to 2.6 and 1.7 percent, 


\section{Figure 1. Korea-The Rebound}

The rebound in economic activity has been impressive, and is increasingly led by private domestic demand.

Contributions to GDP Growth

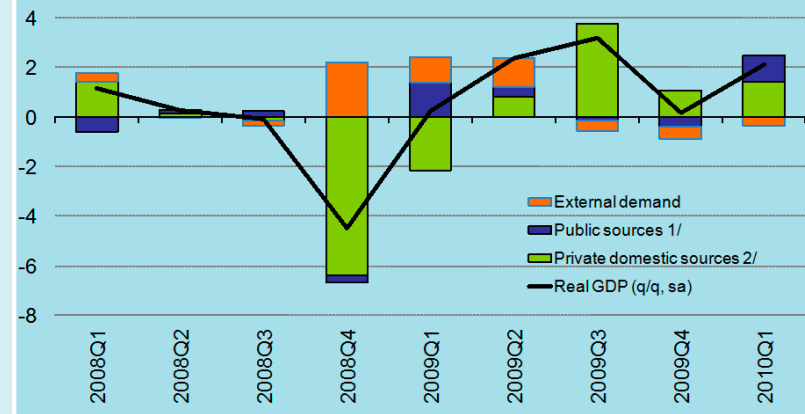

Source: CEIC Data Company Ltd

$1 /$ Construction and public consumption

2/ Residual.

...the normalization of trade,...

\section{Exports By Destination}

(3mma of y/y percent change)

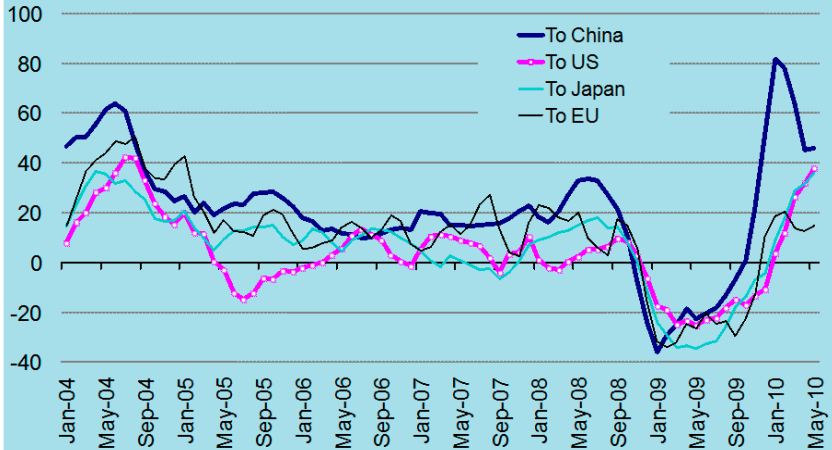

Source: CEIC Data Company Ltd

...strong capital inflows,...

\section{Selected Asia: Net Capital Inflows ${ }^{1}$}

(In percent of GDP)

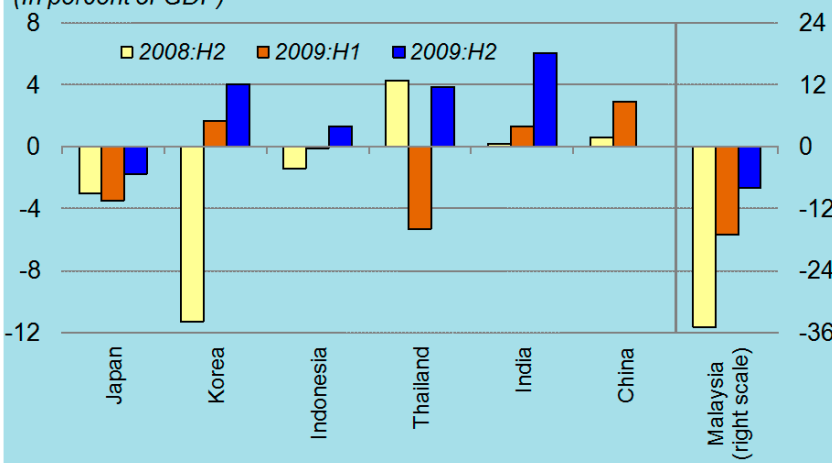

Sources: CEIC Data Company Ltd.; and IMF, Balance of Payments Statistics; and staf calculations.

${ }^{1}$ China's 2009:H2 data are not yet available.
It has been supported by a 325 bps cut in monetary policy rates, substantial global fiscal stimulus,...

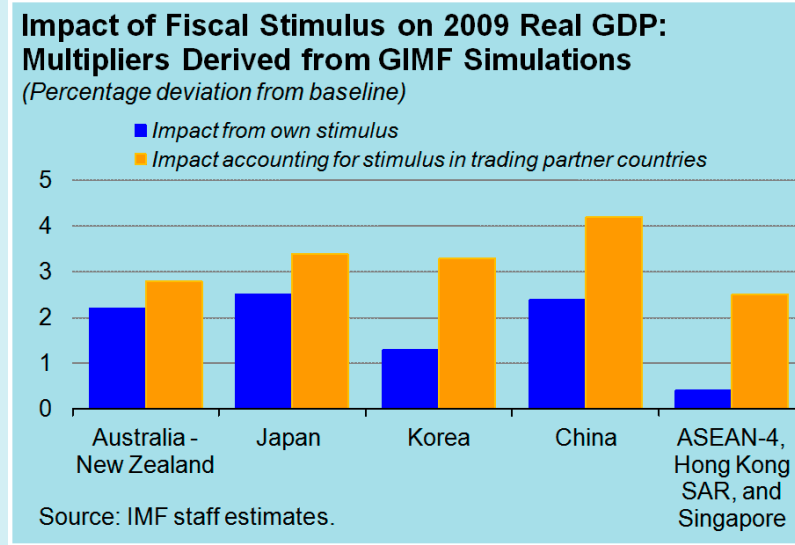

...the turning of the inventory cycle,...

\section{Inventory to Shipment Ratio}

(In percent, 3mma)

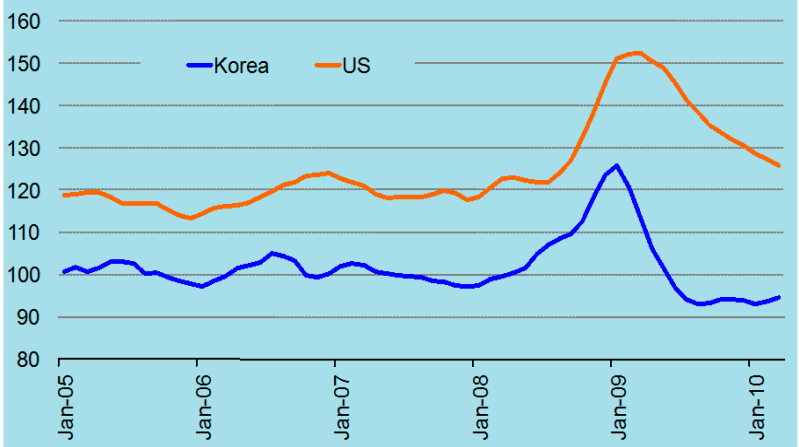

Source: Haver Analytics.

....and the strong balance sheets of the government, large corporates, and banks.

\section{Capital Adequacy Ratio}

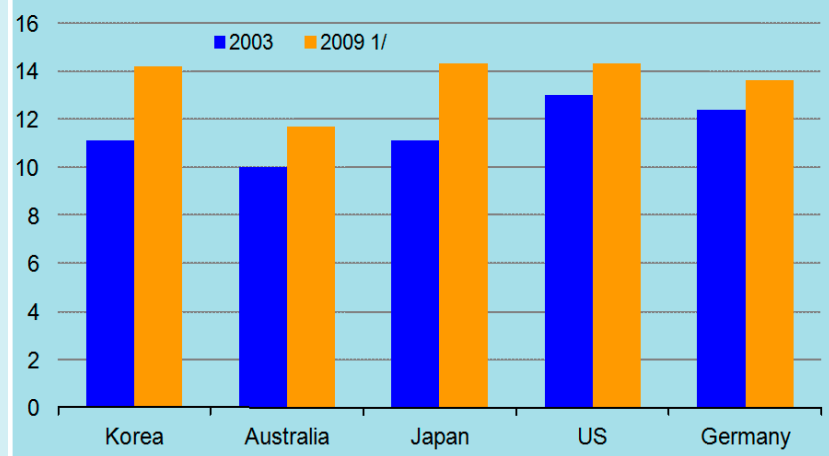

Sources: IMF, Global Financial Stability Report.

1/ For Germany, 2008, for U.S. December 2009, and for others September 2009. 


\section{Figure 2. Korea-Monetary and Financial Market Conditions}

The rebound has not yet manifested itself in inflation pressures.

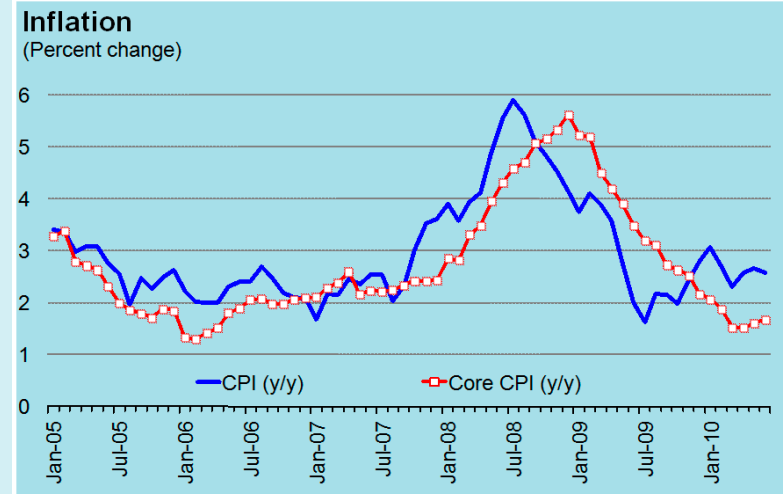

Source: CEIC Data Company Ltd.

... strong capital inflows have boosted equity prices, although the crisis in southern Europe and tensions with North Korea have led to recent declines.

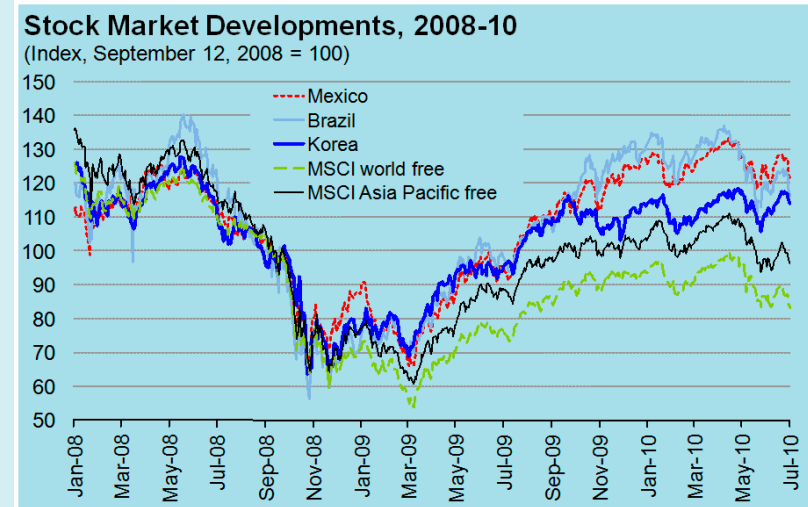

Source: Bloomberg LP.

Financial market conditions have also normalized, although the recent turmoil has led to an uptick in risk premia.

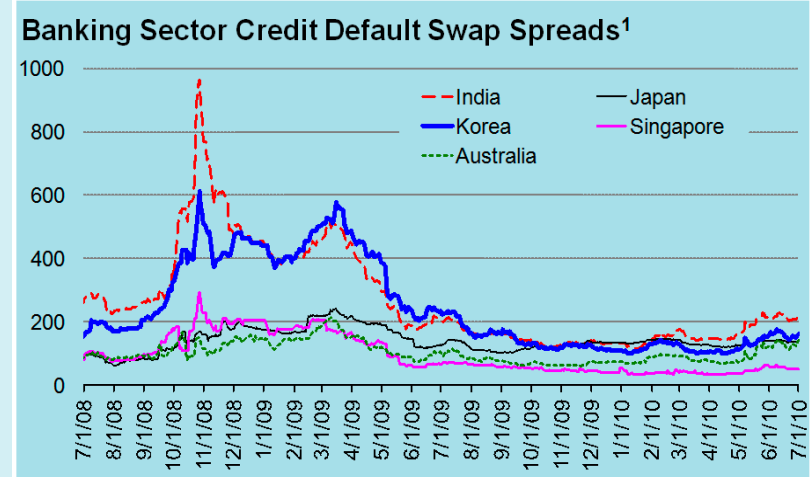

Sources: Bloomberg LP; and IMF staff calculations

${ }^{1}$ Country spreads are weighted averages based on relative assets.
Moreover, the momentum in house price growth has slowed recently, especially in select areas of Seoul, while...

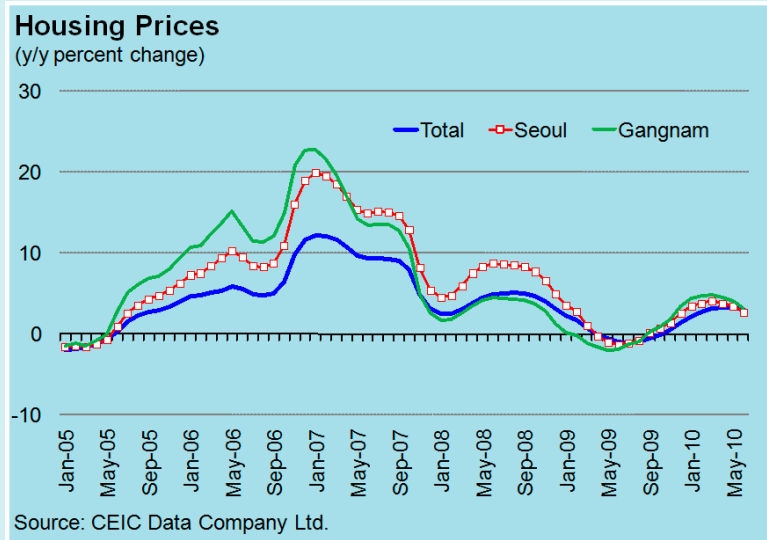

Equity prices have also risen relative to actual earnings since late 2008, reflecting the optimistic outlook for profit growth.

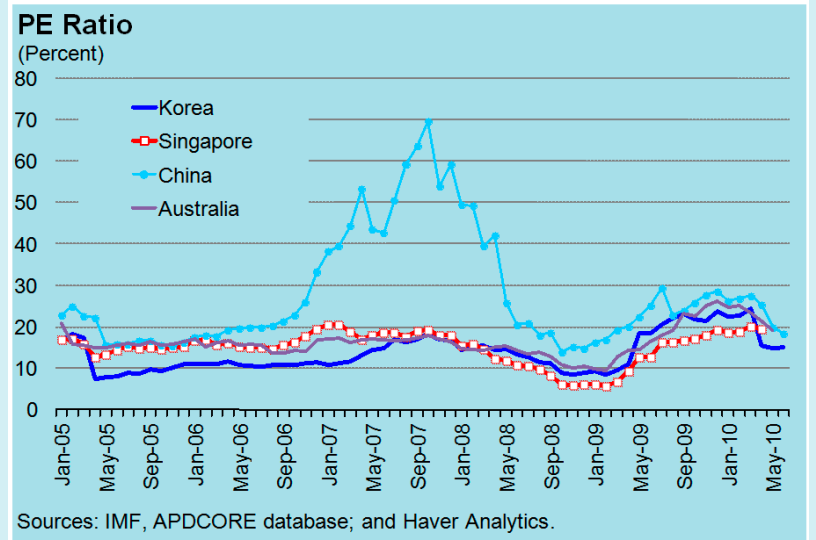

However, the credit cycle has not turned at this stage as banks remain cautious and in response to prudential tightening of mortgage lending last year.

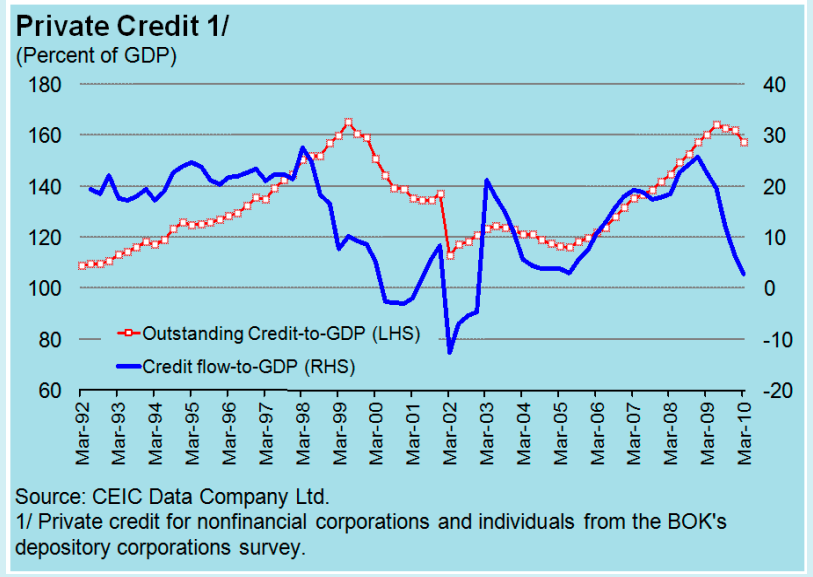


respectively, in July from 2.3 and

1.5 percent, respectively, in March.

Nevertheless, headline inflation remains well within the BOK's inflation target range of $3 \pm 1$ percent.

- $\quad$ Equity and bond prices: With Korea and other Asian economies leading the global economic recovery, capital inflows have rebounded. Renewed investor risk appetite and ample liquidity in the advanced economies have amplified this trend. In Korea, capital inflows have mainly been concentrated in portfolio investments, boosting equity prices. The KOSPI Index has surpassed pre-crisis levels and is at multi-year highs relative to current earnings, despite the recent correction following the onset of the European sovereign debt crisis. Nevertheless, the recovery is not out of line with that experienced after the Asian crisis. Bond markets too have benefited from capital inflows and yields remain low.

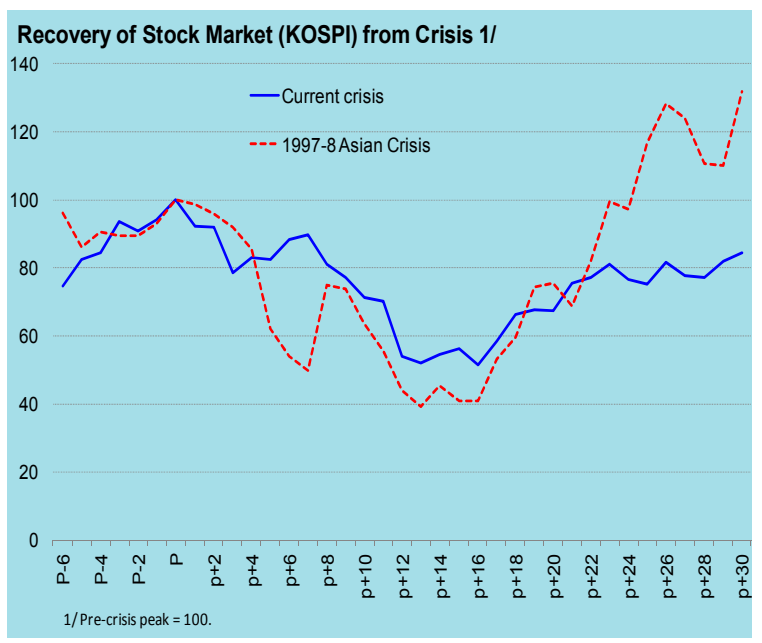

- Property prices: House prices have risen from their lows in early 2009, particularly in select areas of Seoul. For the country as a whole, however, they are only up by around 3 percent $(y / y)$ so far. Also, the momentum has slowed in recent months, partly in response to the introduction of prudential measures last year. Nationwide house prices do not appear to be out of line with fundamentals (income, interest rates), but the large overhang of unsold properties is likely to limit the upside.

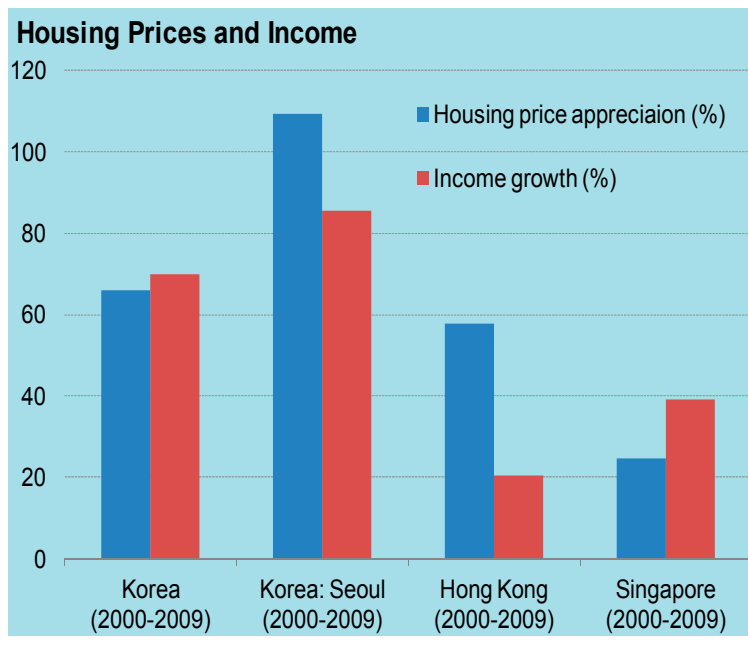

5. While financial market conditions have largely normalized, the credit cycle has not yet turned as banks remain cautious about lending (Figure 2).

- $\quad$ Financial market strains: Measures of financial market strains have largely normalized since the height of the global financial crisis. Credit spreads and volatility (actual and option implied) are back to-and in some cases below-pre-crisis levels. However, the onset of the recent sovereign debt crisis in Europe has led to renewed risk aversion among investors and some uptick in risk premia as well as elevated exchange rate volatility. 
- $\quad$ Credit market conditions: Credit to the private sector has decelerated, led by a slowdown in lending to SMEs and households. In part, this reflects that banks are adjusting to new loan-to- deposit limits and the tightening of prudential regulations for mortgages last year, aimed at quelling the earlier acceleration in housing prices.

\section{B. Outlook and Risks-Ignition of the Private Engine of Growth}

\section{Staff's Views}

6. The economic recovery is projected to be increasingly driven by autonomous private sector demand. Growth is projected to rise to 6.1 percent in 2010 and ease to $4 \frac{1}{2}$ percent in 2011, partly due to base effects and the exit from supportive policies. The recovery is expected to be led by the rebound in fixed investment and the turning of the inventory cycle. Private consumption is also expected to strengthen, although it will be constrained by the usual lagged response of the labor market during upturns and relatively high household indebtedness. The public sector is expected to contribute negatively to growth as fiscal stimulus is withdrawn this and next year (see below). With the strengthening of private demand, the contribution of net exports is expected to be lower.

7. Near-term risks are broadly balanced at the moment. Downside risks relate to the global economic and financial outlook, including a further escalation of the turmoil in southern Europe or worsening geopolitical tensions in the Korean peninsula. These are balanced by the potentially faster recovery in domestic investment and inventories. Should the risks from an escalation of the sovereign debt crisis in Europe materialize (Box 1), Korea would be vulnerable to a squeeze in foreign currency liquidity if European banks are forced to deleverage. The deleveraging could also have broader implications for the global economic outlook, which would adversely affect Korea's exports.

8. Over the medium term, growth is projected to settle below pre-crisis levels. This reflects several factors: weaker export demand from advanced economies as they repair private and public balance sheets; the rapid aging of the labor force; and, the high indebtedness of Korean households and SMEs (see below), which could constrain consumption and investment. In addition, raising productivity in the nontradable sector (the second engine of growth) to the same levels as in the export sector will likely be a prolonged process, making it difficult to fully offset the initial export- and aging-led decline in potential growth. Moreover, increasing productivity in the nontradable sector will depend on the pace of implementation of growth-enhancing structural reforms. The overall slowdown in exports also depends on Korean exporters' ability to penetrate new markets. 


\section{Box 1. Korea: Potential Spillovers from the Crisis in Greece ${ }^{1}$}

The intensification of the crisis in Greece has led to a rise in risk premia for Korea-related exposures. The won has weakened by about 7 percent against the U.S. dollar since end-April and historical and option implied $\mathrm{FX}$ volatility has ticked up. The negative cross-currency swap spreads have widened by more than 100 bps, but there are no signs of severe dollar funding pressures at this point. Risk premia on the Korean government and banks have also risen, but are well below their late 2008 highs. However, these developments have so far been mainly driven by the global rise in risk premia, and more recently by the escalation of tensions with North Korea, and not by Koreaspecific economic circumstances.

While Korean banks' direct exposure to Greece is small, their funding structure does pose risks. Korean banks' direct exposure to Greece is miniscule at $\$ 380$ million out of total assets of $\$ 1,315$ billion. However, Korean banks still rely relatively heavily on wholesale funding, despite a decline since 2008 , but only around 25 percent is from foreign banks. Nevertheless, the large share of external funding from European banks exposes Korea to risks in the event the crisis in Greece deepens and/or spills over to other countries with weak fiscal positions. Since European banks have large exposures to the countries seen as fiscally vulnerable, they could be forced to cut back credit lines to Korean banks or their foreign branches in Domestic Bank Whole Sale Funding and External Debt (US\$ bn)

\begin{tabular}{lrr}
\hline & End-08 & End-09 \\
\hline Total liabilities & 1283 & 1315 \\
o/w Whole sale funding & 413 & 395 \\
\% of liabilities & 32 & 30 \\
o/w External debt & 97 & 104 \\
Short term & 43 & 43 \\
\% of total external debt & 43.9 & 41.7 \\
\% of total liabilities & 3.4 & 3.2 \\
\% of total external debt & 54 & 60 \\
Long term & 56.1 & 58.3 \\
\hline
\end{tabular}

Korea due to increased loss provisioning or capital requirements against their southern European exposures.

Potential sovereign risk contagion would appear small, but the corporate sector faces relatively large dollar-denominated rollover needs. Korea's fiscal position is strong and the size of external government debt is relatively small at 4 percent of GDP, suggesting they are not likely to be singled out by nervous investors. However, corporate dollar-denominated rollover needs are sizeable at close to US\$22 billion during Q2-Q4 2010, although this is small relative to gross official reserves of US\$279 billion.

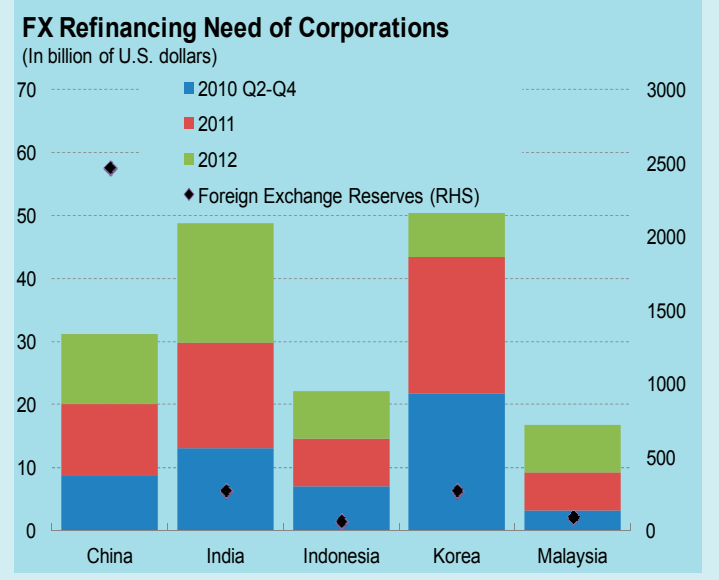

Spillovers through the trade channel would also appear manageable, unless the crisis leads to a global economic slowdown. Less than 3 percent of Korea's exports are to southern Europe, while Europe's share is only around 15 percent. However Korea also exports to Europe via China and around 70 percent of Korea's exports are concentrated in highly cyclical medium- and hightech goods. Therefore, in the event the crisis escalates and spills over to economic activity in Europe at large and causes a depreciation of the euro, Korean exports could suffer.

\footnotetext{
${ }^{1}$ Prepared by Leif Lybecker Eskesen.
} 
The Authorities' Views

9. The authorities broadly agreed with staff's assessment of the economic outlook. The Ministry of Strategy and Finance (MOSF) expects GDP to grow by 5.8 percent in 2010, led by robust domestic demand and exports amid a stronger-than-expected global economic recovery. For 2011, the Ministry forecasts growth of 5 percent. The BOK forecast growth of 5.9 percent and 4.5 percent in 2010 and 2011, respectively. Inflation is projected by BOK to pick up during the second half of 2010 , with average inflation projected at 2.8 percent in 2010 and 3.4 percent in 2011.
10. The authorities also shared staff's views about the risks to the economic outlook. On the downside, they emphasized, in particular, the potential spillovers from an escalation of the sovereign debt crisis in Europe. However, they concurred with staff that the small direct exposure to the highly indebted European countries through trade and financial channels is unlikely to threaten the recovery, unless broader deleveraging and heightened risk aversion emerge. On the upside, they saw scope for exports to outperform despite the developments in Europe given strong performance in other markets, including China. For 2011, they thought the margins of uncertainty were higher.

\section{POLICY THEME \#1-MANAGING THE TRANSITION TO PRIVATE-LED GROWTH}

Over the near term, the main policy challenge is to carefully manage the exit from accommodative macroeconomic and financial sector policies while ensuring an orderly transition to a self-sustained private sector-led recovery. At the same time, the authorities should stand ready to respond appropriately in the event of a sharp rise in global risk aversion related to the stress in European sovereign debt markets.

\section{Background}

11. The $\mathbf{2 0 1 0}$ budget implies significant fiscal withdrawal relative to last year. The 2010 deficit is projected to decline to $11 \frac{1}{2}$ percent of GDP (excluding social security funds) following a deficit of 4.1 percent of GDP in 2009, primarily driven by the nonrenewal of most stimulus measures. While the budget remains supportive relative to the 2007 pre-crisis baseline, it implies a negative fiscal impulse of close to 2 percent of GDP relative to 2009. Based on multipliers derived from the IMF's Global Macroeconomic Fiscal and Monetary model, this will subtract around 1 percentage point from growth this year (Figure 3 ).

\section{Monetary policy remains highly} accommodative and the exchange rate is well below pre-crisis levels. After maintaining the policy rate at 2 percent since February 2009, the BOK raised it by 25 bps in July 2010. Most of the extraordinary liquidity measures have meanwhile expired. With the output gap expected to close before the end of 2010 and the policy rate estimated to be significantly below neutral, the monetary stance is assessed to be highly accommodative (Figure 3). Furthermore, the real effective exchange rate is about 8 percent below pre-crisis levels and financial conditions are also still accommodative. 


\section{Figure 3. Korea-Current Policy Settings}

The 2010 budget implies significant fiscal withdrawal.

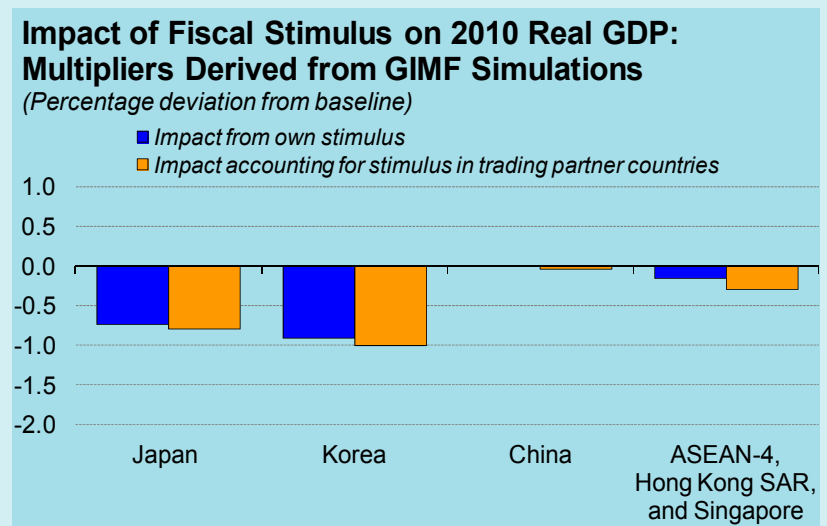

Source: IMF staff estimates.

...in particular in light of the closing of the output gap later this year and the likely increase in inflation pressures,.

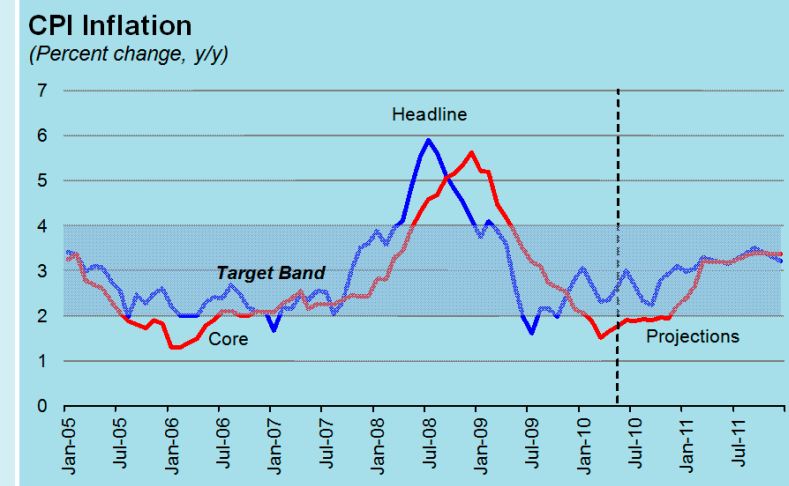

Sources: National Statistical Office and staff calculations.

Despite the rapid appreciation since March 2009, the REER remains well below pre-crisis levels.

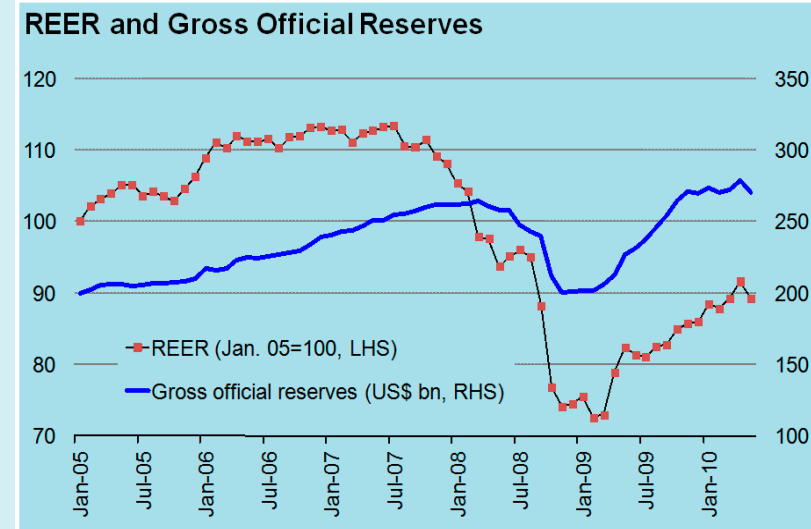

Sources: CEIC Data Company Ltd; and IMF, Information Notice System.
However, monetary policy settings remain very accommodative,...

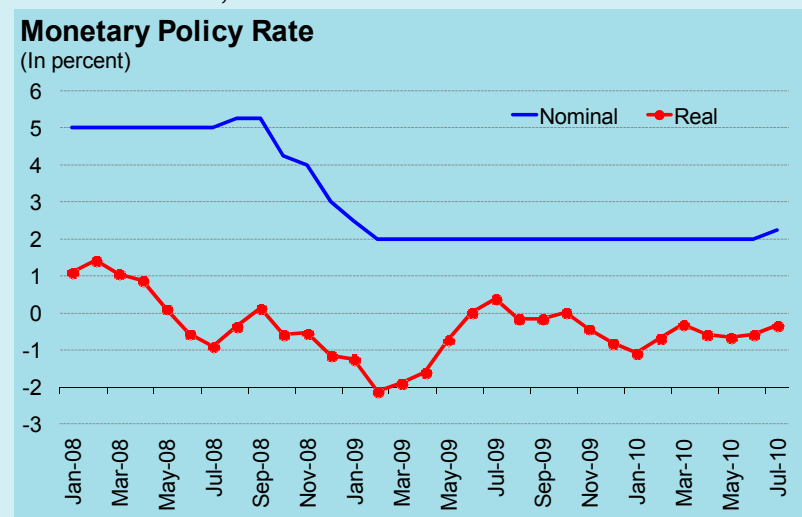

Source: CEIC Data Company.

...which will raise the gap vis-à-vis the neutral rate in the absence of further action.

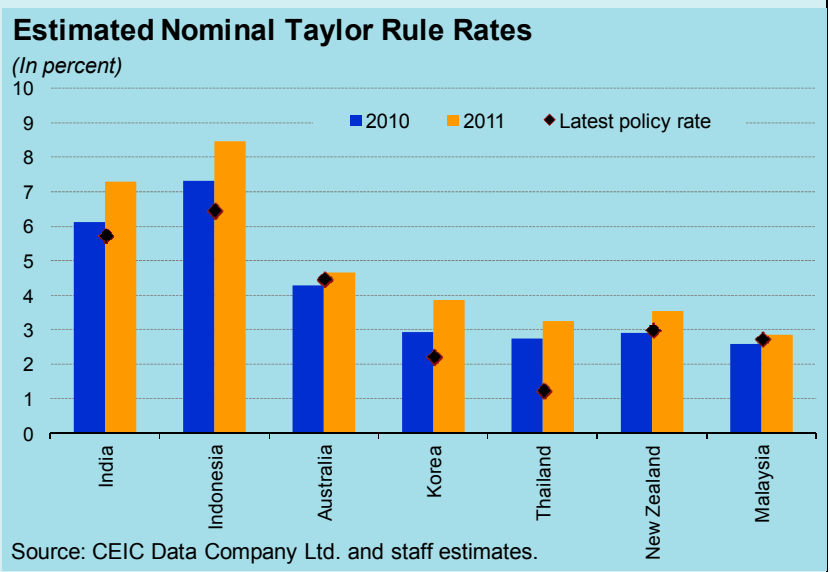

The exchange rate, consequently, remains undervalued relative to its equilibrium level.

\section{Real Effective Exchange Rate Undervaluation} (In percent)

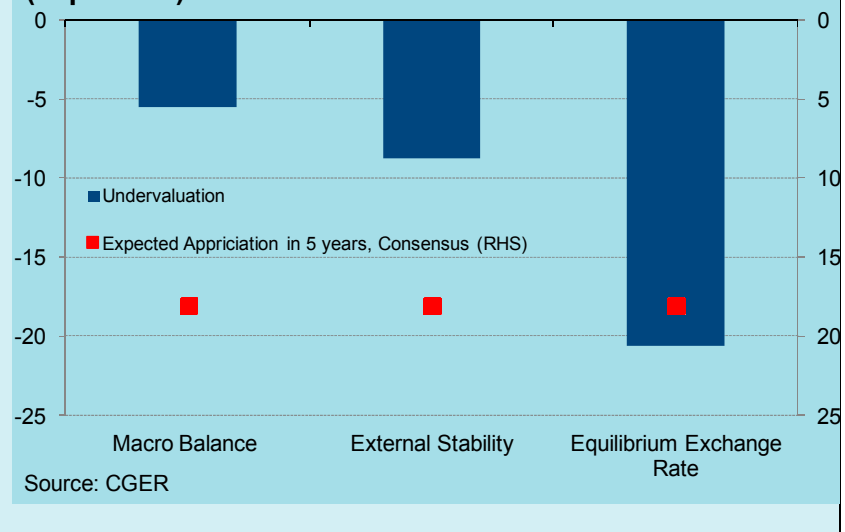


13. Most SME- support measures are being gradually unwound, but many financial sector support facilities remain in place. The commercial bank guidance to rollover maturing SME debt was not renewed in 2010. Also, the maximum coverage of SME loan guarantees was scaled back from 100 to 85 percent as of July this year for existing loans under guarantee and to 50-85 percent for new loans. While the government's guarantee of banks' external debt expired at end-2009, the W 20 trillion bank recapitalization fund is still active, but has not been used since early 2009 when eight banks received capital support (W 3.9 trillion). Korea Asset Management Corporation's (KAMCO) W 40 trillion facility for buying nonperforming assets is also still in force, but utilization was low at $\mathrm{W} 1.2$ trillion. An additional W $2 \frac{1}{2}$ trillion is planned for purchases in 2010 of construction-related nonperforming loans from savings banks.

\section{Staff's Views}

14. To safeguard the private sector-led recovery, the exit from supportive macroeconomic policies should be carefully calibrated. While the recovery is strong, private sector growth is not likely to be fully self-sustained until later in the year. Exit from supportive macroeconomic policies is still appropriate. However, the short transmission lags of fiscal policy, including Korea's ability to quickly adjust fiscal policies, when weighed against the longer lags of monetary policy, suggest that the policy mix could have been tilted more toward monetary tightening and less toward fiscal withdrawal. Nevertheless, the front-loading of the 2010 budget spending will appropriately help smooth the transition to private sector-led growth. For 2011, the authorities should aim for a measured fiscal withdrawal as activity exceeds potential, relying more on revenueraising measures given Korea's narrow tax bases by OECD standards. In the near term, it would also be appropriate to raise policy rates further after the welcome July hike (Box 2). In this context, the MOSF may wish to review its recent practice of attending monetary policy meetings and voicing views publicly on the appropriate monetary policy stance. In line with best practices on independent monetary policy frameworks in other advanced economies, this would help strengthen the credibility of the monetary authorities.

15. Exchange rate flexibility should also be a key element of the policy mix. Despite the 22 percent appreciation between March 2009 and June 2010, the real effective exchange rate remains undervalued according to IMF's Consultative Group on Exchange Rate issues (Figure 3). The exchange rate should be allowed to fully reflect supply and demand conditions in the foreign exchange markets, with interventions being strictly limited to smoothing operations.

\section{With economic and financial} conditions normalizing, the scaling back of SME and financial sector support should continue. Staff welcomes the planned steps to reduce the amount and coverage of SME loan guarantees. However, the authorities are urged to further reduce the coverage to minimal levels for all loans over the medium term. With financial conditions having normalized since end-2008, the bank recapitalization fund, the KAMCO fund and other remaining financial sector support measures can now be unwound without threatening the recovery. 


\section{Box 2. Time for Monetary Policy Normalization in Korea? ${ }^{1}$}

Asia's faster-than-expected recovery has already brought forward a gradual normalization of monetary policy. Central banks in Australia, India, Malaysia and Thailand have raised policy rates, fueling expectations that central banks in other countries that are growing robustly will follow suit in 2010 . The analysis in this box supports the case for gradually normalizing the policy rate in Korea and suggests that the rate may have to be raised relatively rapidly once the private-led recovery has become fully self-sustained.

Why is it the right time to start normalizing the policy rate in Korea? To address this question, one approach is to estimate the "neutral" interest rate, consistent with no output gap and stable inflation. The approach applied here is based on the estimation of a structural macroeconomic model for Korea. In the model, the real neutral interest rate is determined by movements in trend output, which is derived from a Ramsey-type optimal growth model. The neutral rate also depends on the risk premium because it has a bearing on economy-wide borrowing costs, impacting the monetary policy transmission mechanism. The main findings are as follows:

- Output gap: The onset of the global crisis led to a downward shift in the level of potential output in Korea. However, actual GDP fell even further, leading to a significant output gap in late 2008 and early 2009. Despite a subsequent recovery in potential output, the gap started to narrow rapidly as the Korean economy rebounded from the crisis and the gap is likely to close during the second half of 2010. These developments are in line with the experience of the Korean economy during the

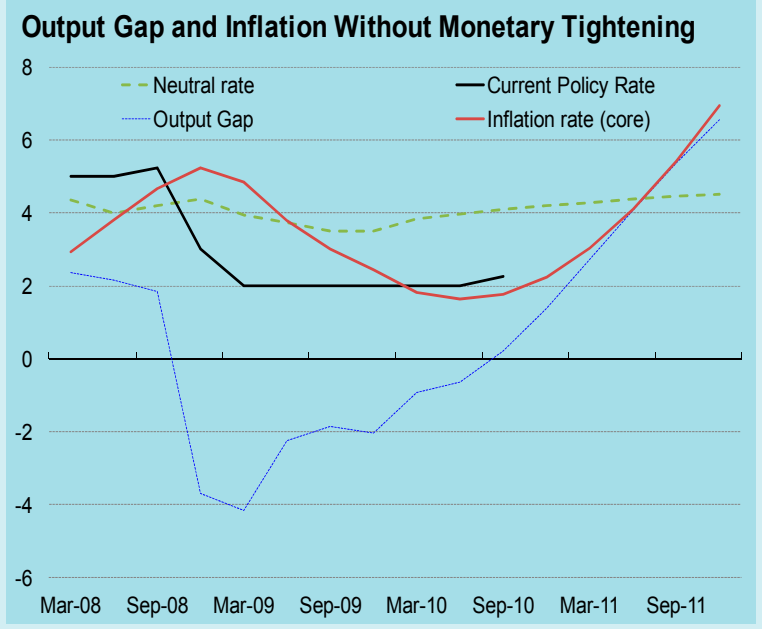

Asian financial crisis, when it took an average of 67 quarters for the output gap to close.

- Neutral rate: The neutral interest rate declined during the crisis, reflecting the decline in potential output and the increase in the risk premium due to the global financial turmoil. In total, the neutral rate declined by about 100 basis points to $3 \frac{1}{2}$ percent, close to the historical low. As the recovery firmed and financial markets stabilized, the neutral rate has risen. Looking ahead, it is estimated to rise another $75-100$ basis points by 2011 as potential output trends up and the risk premium declines further with the normalization of conditions in global financial markets. However, it should be noted that the level of the neutral rate is difficult to determine precisely, especially during significant downturns impacting not only supply and demand conditions but also the functioning of credit markets.

The prevailing policy rate is well below the neutral rate, reflecting the highly accommodative monetary policy stance in Korea. At 2.25 percent, the current policy rate is well below neutral; by around 200 basis points from model-based estimates, which of course have to be interpreted with caution. Moreover, in the absence of further policy rate hikes or in the event of a very gradual normalization, monetary conditions will become even more accommodative as the neutral rate rises further. Policy simulations show that a gradual 200 basis points rate hike, starting in Q3 2010, would postpone the closing of the output gap until early 2011.

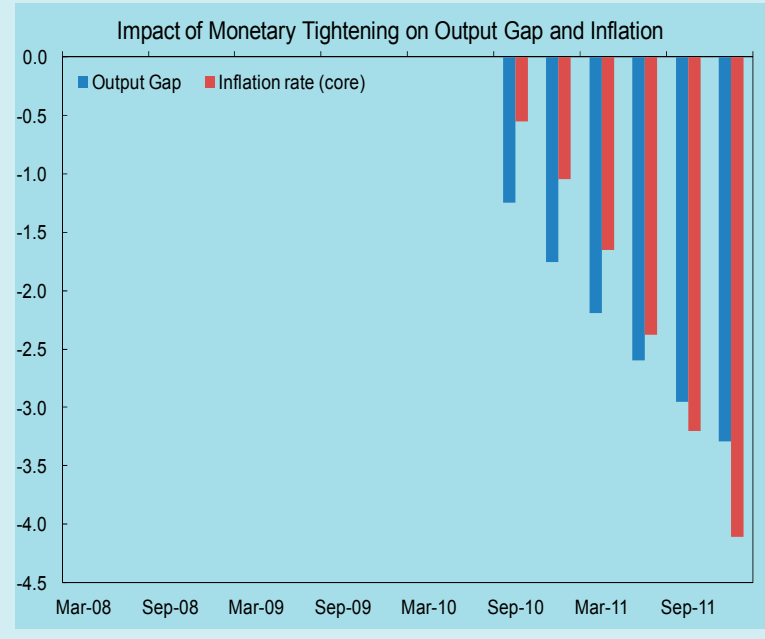

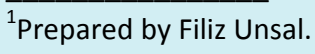


17. An escalation of the crisis in southern Europe and worsening geopolitical tension in the Korean peninsula could impact the timing and pace of exit. The most immediate fallout in both cases would be a squeeze in foreign currency liquidity as European banks and/or global investors scale back their Korean exposures. In that case, the BOK could use its ample reserves to provide swaps and loans as substitutes for foreign currency funding. In the event of a more extreme outcome, swap lines with foreign central banks may need to be reactivated. If the crisis in Europe has implications for the global economic outlook, and risks causing a "second dip," an adjustment of macroeconomic policies may be called for. However, if the sovereign debt crisis primarily results in a gradual and sustained downward shift in European growth due to fiscal tightening, the appropriate policy response in Korea would be structural reforms rather than demand-management policies.

\section{The Authorities' Views}

\section{The authorities agreed that it was} time to gradually scale back the supportive policy measures, but that it should be done in a cautious manner. While the 2010 budget implies significant withdrawal of stimulus relative to 2009, they underscored that it is still expansionary relative to the pre-crisis benchmark. This reflects the continuation of priority support measures such as the "Hope
Employment Program," (scaled back) SME support, and other initiatives to smooth the transition to fully private sector-led growth. For 2011, they plan continued fiscal withdrawal, mindful of the cyclical position of the economy. As part of a carefully managed exit strategy, the authorities believed that monetary policy should remain accommodative and not be tightened too quickly given the lingering global economic risks. In the event the crisis in Europe escalates and has global economic implications, the authorities stand ready to take appropriate measures.

19. The authorities shared staff's view that exchange rate flexibility is key to ensure an appropriate policy mix. They noted that the exchange rate depreciated rapidly when the global crisis unfolded and subsequently appreciated significantly with the recovery. They stressed that the exchange rate is freely determined in the market and that interventions are limited to smoothing operations.

20. While SME support measures were gradually being scaled back, some financial support facilities are being retained for now. While the authorities plan to take further steps in coming years to scale back SME support, they were reluctant to unwind financial support measures, preferring to keep them in place for now as a safety net until downside risks had receded further.

\section{POLICY THEME \#2-SECURING ECONOMIC RESILIENCE AND SUSTAINABLE GROWTH}

Korea's economy is very open to trade and financial flows. Over the medium term, the authorities should enhance macroeconomic and financial policy frameworks to improve the economy's resilience and the ability to respond to shocks. In addition, product and labor market reforms should focus on strengthening the nontradable sector. This will be key to sustaining growth in the face of softer 
exports to advanced economies and to reduce the economy's vulnerability to external demand shocks.

\section{A. Enhancing Macroeconomic Policy Frameworks}

Fiscal Policy-Resuming Consolidation and Cementing Credibility

Background

21. Korea has a strong fiscal position by international standards, but is faced with a rapidly aging population. The government is, therefore, targeting a balanced central government budget (excluding social security funds) by 2013-14. The consolidation is likely to be primarily driven by expenditure restraint, including the unwinding of the temporary stimulus measures. However, no significant details have been articulated on the discretionary measures to achieve the fiscal consolidation. While the social security funds are currently in surplus, the asset position of the pension fund is projected to be depleted around 2050-60 absent further reforms. Looking at the broader public sector, the government also faces contingent liabilities associated with loan guarantees and the buildup in recent years of public enterprise debt (around 20 percent of GDP). Korea Land \& Housing Corporation (KLHC) alone accounts for around half of this debt, related to its affordable-housing construction and associated land purchases.

\section{While the government operates} under a fiscal framework, the targets are not legally binding and often subject to revisions. The National Fiscal Management Plan (NFMP) and the National Debt Management Plan (NDMP) include objectives on the size and distribution of expenditures, the fiscal balance, and debt. The NFMP covers the central government, including special accounts and public funds. However, the objectives set in the NFMP and NDMP are not supported by a formal fiscal rule. Moreover, the aggregate spending ceiling is revised every year to ensure linkage with the annual budget, and, therefore, is not binding. Local governments are subject to a balanced budget rule and a total borrowing ceiling, which is monitored by the central government.

\section{Staff's Views}

\section{The "Great Recession" underscored} the importance of having room to conduct counter-cyclical fiscal policy, as effectively demonstrated by Korea. In addition, Korea needs to create room to accommodate the fiscal costs associated with the rapid aging of the population. Staff agrees with the broad contours of the authorities' medium-term consolidation plan and the balanced budget is an appropriate intermediate target. However, more details on underlying measures would help strengthen credibility. On the revenue side, the adjustment could be brought about by broadening the base for personal and corporate income taxes and VAT. There would also seem to be scope to raise the VAT rate and social security contributions. On the expenditure side, non-age-related outlays could be streamlined, which would help provide room for a needed expansion of the social safety net. Additional pension reforms should also be considered to ensure longterm sustainability of the pension fund. Further to this, the authorities are urged to 
take more decisive steps to strengthen the financial position of public enterprises.

24. A further formalization of the fiscal framework could help better anchor fiscal policy. In addition to publishing detailed medium- term fiscal consolidation plans, including details on policies to achieve the fiscal targets, another possibility would be the adoption of a fiscal rule for the general government. This would make fiscal targets more binding and strengthen prioritization among fiscal measures. In this context, it may be worth considering a rule targeting the structural fiscal balance combined with spending and debt targets. Moreover, linking the fiscal targets more directly to future liabilities, including those related to aging, would help ensure that the fiscal objectives are consistent with long-term sustainability. In this context, it will also be important to take further steps to enhance fiscal transparency, including regarding contingent liabilities, to allow for better monitoring and assessment of fiscal risks.

\section{The Authorities' View}

25. The authorities broadly agreed with many of staff's proposals on revenue and expenditure reforms. They acknowledged the scope to provide more details on the measures underlying their medium-term consolidation plans and planned to shed more light on these when the 2011 budget is presented later this year. They broadly agreed with staff's proposals to achieve fiscal consolidation, but were still in the early phase of designing reforms.

26. The authorities are considering steps to further formalize and strengthen the medium- term fiscal framework. The National Finance Act was revised in April 2010 to make the NFMP and NDMP more effective, including by publishing more details relating to the medium-term fiscal outlook and the evaluation of the previous year's NFMP. The authorities are also considering the introduction of a fiscal rule, but have at this stage not decided on the exact rule. They saw merit in strengthening the analysis of the long-term fiscal outlook and assessment of future fiscal risks to help them better determine a sustainable fiscal path. On public enterprise debt, they were somewhat more sanguine because KLHC debt, for example, is backed by land and real estate assets.

\section{Monetary Policy-Broadening Objectives and Strengthening Coordination}

\section{Background}

27. The BOK's primary policy objective is price stability, but proposed revisions to the central bank law could legally add financial stability as an objective. The BOK has operated an inflation targeting framework since 1998. However, the BOK has also established financial stability as one of its core objectives consistent with its lender-oflast resort role. But, a revision to the Bank of Korea Act calling for the BOK to pay attention to financial stability is still awaiting debate in the National Assembly.

\section{The global crisis has raised} awareness about potential weaknesses in the current institutional arrangements for systemic risk management. In response, the authorities have already taken some measures, including the signing last year of a Memorandum of Understanding (MOU) between the MOFS, the BOK, the Financial Supervisory Services (FSS), the Financial Services Commission (FSC) and the Korea Deposit Insurance Corporation to share more 
information about individual financial institutions. This was in recognition of information deficiencies that came to light when the BOK liquidity facilities were extended to a broader set of financial institutions.

\section{Staff's Views}

29. The global crisis has demonstrated how "benign neglect" may have allowed for a buildup of asset price bubbles and excessive leverage in some economies. Moreover, asset price inflation can have implications for economic activity and inflation through wealth and confidence effects. While overall price stability should remain the BOK's primary objective, it may be appropriate to consider broadening the monetary policy framework to explicitly allow for discretionary policy responses ("leaning against the wind") in the event of sustained asset price inflation or the pro-cyclical buildup of leverage, should it be judged to have a bearing on the inflation outlook and/or macroeconomic and financial stability (Box 3 ).

30. There is also scope to further enhance the coordination between the BOK and the supervisors/regulators during "normal" times to better internalize macrofinancial linkages. This is important to better align the institutional arrangements with cross-agency responsibilities, including BOK's role with respect to financial stability in light of its lenderof-last resort function. It is also critical because of the inter-relation between monetary policy and financial stability. Financial instability could, for example, be exacerbated if the monetary policy rate is set too low, leading to excessive leverage or generalized asset price inflation. At the same time, policy rates may be a blunt tool for addressing financial instability if it arises from factors such as localized housing bubbles, which may initially require a macroprudential response. Moreover, the BOK is well placed to analyze overarching systemic risks and macrofinancial linkages, areas of key importance for the assessment of financial stability.

\section{The current coordination} mechanism, while having proven effective during the recent crisis, still has room for improvement along several dimensions. The current framework involves multiple channels of policy coordination and risks leading to perceptions of political interference in the design of financial stability policies. This could undermine the perceived independence and effectiveness of the various agencies tasked with different aspects of financial stability. Current institutional arrangements also make it less clear which agency is best placed to develop the needed analytical capacity for analyzing macrofinancial linkages. To address this, one option that broadly preserves the current overall institutional arrangement could be the establishment of a permanent "Financial System Stability Council" with representation of all agencies that are charged with financial stability responsibilities. This would serve as a formalized coordinating framework, but with institutional safeguards ensuring that monetary policy is decided independently by the BOK's Monetary Policy Committee. Such a council would give the BOK an opportunity to provide ongoing input into macro-prudential policies, which could still rest with FSC/FSS. It would also strengthen information sharing and understanding of macrofinancial linkages, including through joint stress testing and cross-fertilization of comparative skills and knowledge. In this context, it will be particularly important to strengthen the analytical tool kit for macrofinancial analysis and expertise within the BOK given the 


\section{Box 3. A Role for Asset Prices in Korea's Monetary Policy Framework? ${ }^{2}$}

Inflation targeting (IT) has been a key element of the robust macroeconomic framework in place in Korea. The BOK's IT framework has helped successfully anchor inflation while supporting growth, but may benefit from focusing on a broader set of potential sources of inflation. In practice, the BOK has applied IT flexibly by also "keeping an eye" on asset prices. Considering the role played by asset bubbles in the global crisis, one option may, therefore, be to broaden the monetary policy framework to more systematically account for asset prices. In fact, a structural model for Korea suggests that incorporating asset prices in the framework could help meet the inflation target more frequently and reduce output volatility.

There are generally two schools of thought with regard to the role for asset prices in the conduct of monetary policy. The "benign neglect" camp suggests that monetary authorities should only deal with the financial instability that may result from a collapse of asset prices, but should not adjust monetary policy preemptively as it is difficult to identify a bubble. A competing view is that the central bank should "lean against the wind" through preemptive tightening to prevent the buildup and subsequent collapse of a bubble. While identifying a bubble is challenging, the costs of the bursting of a bubble are too great to overlook. Our rationalization of why asset prices matter is two-fold. First, changes in asset prices can influence economic activity through wealth and confidence effects. Second, forward looking monetary policy decisions could benefit from information embedded in asset prices about expected changes in inflation and the output gap.

To illustrate the potential implications of explicitly incorporating asset prices into practical policy making in Korea, an augmented monetary policy rule is presented here. It is assumed that the central bank would react to movements in asset prices only if the filtered growth rate of asset prices (adjusted for the filtered growth rate of output) deviates significantly from the inflation target over a few consecutive periods. ${ }^{1}$ The intuition is that if asset prices move in line with output and hence inflation in the longer term, then a persistent change in the growth of asset prices may signal a shift in trend inflation. In turn, this would imply an interest rate rule of the form: $i_{t}=i_{t \mid t-1}^{\text {Taylor }}+i_{t}^{M}$ , where $i_{t}^{\text {Taylo }}$ is the interest rate implied by the conventional Taylor rule. $i_{t}^{M}$ is the additional reaction, which only becomes operational if the deviation between filtered asset price growth and the inflation target is significant over an extended period. This rule implies that even under low and stable inflation, the central bank may choose to "lean against the wind" in response to emerging asset bubbles and potential overheating. In fact, there have been cases in the past where policies have responded to asset market developments. Recently, for example, the Swedish Riksbank justified the hike in the policy rate in October 2009 by the pointing to the rise in house prices, even though inflation appeared to be on target.

Applying this monetary policy rule to Korea suggests that its application may strengthen inflation targeting and lessen output volatility. As an illustration, we compare the stabilization properties of the traditional Taylor rule with that of the augmented framework for Korea incorporating asset prices. Simulations suggest that the augmented framework may help the central bank react more systematically to emerging overheating in the economy as signaled by sustained asset price inflation, in addition to the output gap. Indeed, the deviation of inflation from its target and the size of the output gap are shown to be much smaller under the augmented rule, although the impact on the variance is neglible. Thus, the augmented framework can be a useful approach to stabilize output and inflation by making better use of market information.

\begin{tabular}{lcccc} 
& \multicolumn{2}{c}{ Inflation Deviation from Target } & \multicolumn{2}{c}{ Output Gap } \\
\hline & Mean & Variance & Mean & Variance \\
\hline Without asset prices & 1.27 & 3.9 & 2.69 & 16.75 \\
With asset prices & 0.02 & 3.8 & 0.21 & 16.72 \\
\hline
\end{tabular}

${ }^{1}$ Filtered growth rate for variable $S$ (in log) is calculated as: $\Delta s_{t}{ }^{f}=\Delta s_{t-1}{ }^{f}+\gamma\left(\Delta s_{t}-\Delta s_{t-1}{ }^{f}\right)$ where $\Delta$ denotes the first difference operator.

${ }^{2}$ Prepared by Filiz Unsal. 
importance of central banks in financial stability. ${ }^{2}$

\section{The Authorities' Views}

32. The authorities viewed the current monetary policy framework as broadly appropriate, but also saw merit in "leaning against the wind." With the current inflation target range of $3 \pm 1$ percent, the central bank has flexibility to react to other factors, including asset prices. However, the recent global economic crisis had compelled them to look more closely at asset prices and consider the merits of broadening the monetary framework to allow for discretionary responses to asset prices. They also considered that this broadened monetary framework may be better aligned with their responsibility of also safeguarding financial stability.

33. The authorities in general saw little scope for upgrading and formalizing their current framework for inter-agency coordination. The authorities noted that their current coordination framework had worked well during the crisis and were of the view that it was well suited for normal times. There had also been progress on coordination, including through last year's MOUs on information sharing. The authorities did recognize that a more formalized coordination framework would improve the transparency of the coordination process, but it was also noted that this would not necessarily result in effective coordination. Moreover, it was pointed out that the establishment of the council would involve significant changes to the legal framework underpinning the relevant institutions. However, the BOK saw merit in a macroprudential framework where they would play a more active role. In the BOK's view, this would be in line with recent trends in major advanced economies (including the United States, United Kingdom, and other European countries) of a stronger macroprudential role for central banks.

\section{B. Safeguarding Financial Sector Stability}

\section{Background}

34. The soundness of Korea's financial sector was crucial to the resilience of the Korean economy during the global crisis. Korean banks entered the 2008 crisis well capitalized and with low nonperforming loans, although their reliance on wholesale funding proved to be a vulnerability. Since the crisis, banks have raised their average CAR to 14.6 percent, 2 percentage points above precrisis levels. Moreover, nonperforming loan ratios have remained low on average, partly due to significant write-offs, but remain high for (nonsystemically important) savings banks exposed to ailing construction companies.
35. In recognition of some of the vulnerabilities facing the financial sector, the authorities have preemptively taken a number steps. To address vulnerabilities associated with wholesale funding, the loanto-deposit ratio will be capped at 100 percent from 2014, and stronger foreign currency liquidity standards have been introduced to reduce maturity mismatches and improve the quality of liquid assets. Prudential steps have

\footnotetext{
2 See Hyun Song Shin, Risk and Liquidity (Clarendon Lectures in Finance) (2010) pp. 171-75.
} 
recently been taken to limit banks' foreign currency forward positions (related to exporters' hedging) and the associated external debt position - the forward position is limited at 50 percent and 250 percent of capital for domestic and foreign bank branches, respectively. Moreover, exporters' hedge ratio has been capped at 100 percent to reduce speculative demand for forward contracts, and regulations for domestic foreign currency lending have been tightened.

\section{Staff's Views}

36. In light of the lessons from the global financial crisis, there is a need in Korea, as elsewhere, to further upgrade regulatory and supervisory frameworks. Staff supports the recent measures taken by the authorities and their readiness to adopt the tighter regulatory and supervisory frameworks emerging from the international debate. The measures taken thus far are likely to reduce the banking system's vulnerability to abrupt shift in the availability of foreign currency liquidity. Looking forward, the outcome of discussions on core-funding ratios, the treatment of foreign-bank branches, countercyclical capital charges and other measures to reduce the procyclicality of leverage will be particularly important for Korea. As the full implication of all the impending changes become clearer, the authorities may have to stand ready to revisit the design of some of the preemptive measures. As pointed out during previous Article IV consultations, there is also scope to improve stress testing within banks and the regulators and the FSAP update envisaged for early 2011 will follow up further on this and other broader issues.

37. The likely future changes in the financial architecture in Korea could pose new risks and may call for a further recalibration of frameworks. The 2009 Financial Investment Services and Capital Markets Act (FISCMA) opened the door for consolidation of the securities industry and the emergence of domestic investment banks. It will also likely serve to make the nonbank financial sector an increasingly important player in the financial markets. Although increased competition should generate efficiency gains and improve the allocation of capital, it may also increase banks' dependence on wholesale funding as new financial services and instruments provide alternatives to bank deposits. Moreover, it is likely to make financial markets and risks more complicated to monitor and supervise. These implications place a premium on ensuring that supervision, regulation, and the PCA and resolution frameworks, and the lender-of-last resort function are adequately calibrated to deal with the changing financial architecture. In this context, the authorities should also be mindful of the systemic risks associated with further consolidation, including through the establishment of "mega banks" in the already highly concentrated banking sector.

38. Staff shares the authorities' concerns regarding Korea's vulnerability to the potentially destabilizing effects of volatile international capital flows. The recently introduced package of foreign currency related measures will help limit the speculative component of the forward hedges of corporates, and reduce the volume of short-term external debt of banks and their foreign currency maturity mismatches. However, the measures are unlikely to substantially reduce the economy's vulnerability to sudden stops, as the channel of transmission of international shocks related to short-term bank debt may partly 
shift to portfolio flows. For an exportdependent economy with an open capital account, the best line of defense remains a freely floating exchange rate to avoid generating expectations of one way bets that may lead to higher than optimal hedge ratios or carry trades. In addition, measures to further strengthen the financial sector would also enhance the ability of the economy to cope with externally generated shocks, including through macroprudential measures. Moreover, the authorities should be mindful of the impact of any measures on foreign exchange liquidity, since a reduction in liquidity could increase the volatility of the won. The authorities may also wish to further analyze the potential consequences for liquidity management of multinational banks facing different requirements in different countries.

\section{The Authorities' View}

39. The authorities re-emphasized their readiness to adopt new measures emerging from international consensus on regulatory and supervisory frameworks. They generally agree with the current proposals being discussed by international bodies, although they suggested a need to allow for flexibility across countries. The authorities concurred that the potential change in the financial architecture, partly driven by the FISCMA, could imply new and more complicated risks, but explained that they had already taken steps to address these, including by strengthening consolidated supervision of bank holding companies. Moreover, the authorities are committed to monitor the evolution of the financial sector closely and calibrate the regulatory and supervisory frameworks accordingly.

40. The recently introduced foreign currency measures are prudential and intended to reduce capital flow volatility within the current framework of an open capital account. The measures were intended to strengthen the soundness of the financial sector by lowering its exposure to external short-term debt. While the authorities noted that some of the hedging-related transactions may move offshore, they suggested that additional costs may discourage corporates. They also recognized that these measures would not have much impact on overall capital flows in and out of Korea's liquid equity and bond markets. They agreed with staff that a flexible exchange rate and a sound financial sector are the best defense against capital flow reversals.

\section{Product and Labor Market Policies-Diversifying the Sources of Growth}

\section{Background}

41. Korea has relied heavily on its export engine to deliver growth over the past few decades, but this has also made the economy vulnerable to external shocks. Moreover, import demand from advancedeconomies is likely to be smaller in a post- crisis environment where private and public sector balance sheets have to undergo repair. Consequently, the economy will have to rely more on the nontradable sector as a second growth engine and to make the economy more resilient to external shocks, although this is complicated by the relatively weak balance sheet positions of both SMEs and 
households. ${ }^{3}$ Moreover, a real appreciation of the exchange rate would also provide impetus for diversifying the sources of growth.

\section{Staff's Views}

\section{A top priority is to reduce the} productivity gap between the tradable and nontradable sectors. To raise productivity in the nontradable sector it is, as previously recommended, important to step up efforts to expedite bank-led restructuring of the heavily indebted SMEs, open the service sector to more competition by lowering entry barriers and making it easier for foreign companies to invest in Korea. Eliminating the preferential tax treatment of the exportoriented sector would also help rebalance growth away from the export sector.

\section{It will also be key to support the} supply-side transition through labor and social policy reform. As previously recommended, there is scope to reduce the high level of employment protection for regular workers to raise labor market flexibility and employment growth. ${ }^{4}$ However, any easing of employment protection should be accompanied by an expansion in the social safety net for both regular and nonregular workers to provide some income protection in case of layoffs. More focus on education (including tertiary) and training linked to the service sector, targeted at both regular and nonregular workers, could also support growth in the nontradable sector. Moreover, raising participation rates of women and elderly would counter the aging-related decline in the labor force.

\section{The Authorities' Views}

44. The authorities recognize the need to rebalance growth towards the nontradables sector and have already taken several initiatives to this effect. They plan to scale back SME guarantees further over the medium term and issue them more selectively, focusing on promising start ups. The government will continue with the implementation of the plans announced in recent years to develop the service industry: A number of service industries were chosen on the basis of potential for job creation, value added, and growth and will be nurtured through streamlined regulation and increased competition. The government has also signaled its intention to equalize tax treatment between the manufacturing sector and the service sector, although by extending preferential tax treatment to selected services. They recognize that employment protection is high and in practice more than prescribed by the law, but regular workers at large companies are reluctant to reduce it. They also see a need for a better skills match and have launched a number of measures to address this, including by linking government funding for universities to their ability to find relevant jobs for their graduates. In the area of labor reform, the government is considering ways to facilitate part-time employment and extend daycare facilities, as this should help to raise the share of women, students, and elderly in the labor force. There are also efforts under way to address the adverse employment implication of the seniority-based wage system, including by introducing a "wage-peak system."

\footnotetext{
${ }^{3}$ See Selected Issues Paper for further details on rebalancing and indebtedness.

${ }^{4}$ Please see Selected Issues Paper for details on the impact of employment protection on labor dynamics.
} 


\section{STAFF APPRAISAL}

45. The Korean economy has staged an impressive recovery since early 2009 thanks to the authorities' supportive policies, and the normalization in global trade. Growth is expected to rebound to 6.1 percent in 2010 and moderate to $4 \frac{1}{2}$ percent in 2011 , with economic activity increasingly led by the private sector. Near-term risks to this baseline appear broadly balanced at the moment.

46. In light of the strong economic recovery, a carefully calibrated exit from supportive macroeconomic policies is appropriate. While the 2010 budget is estimated to subtract around 1 percentage point from growth, monetary policy remains highly accommodative, somewhat beyond what is necessary to support the recovery. It is appropriate for the BOK to continue to gradually raise the policy rate and the recent hike is a welcome start. To further raise the policy rate would still leave monetary policy highly supportive of the recovery that is being anticipated in the baseline. A measured fiscal withdrawal in 2011 would be appropriate with the economy above potential. Preserving flexibility of the exchange rate is also a key element of this exit strategy. At the same time, the authorities should stand ready to respond appropriately in the event of a sharp rise in global risk aversion related to the stress in European sovereign debt markets.

47. The announced steps to scale back the amount and coverage of SME guarantees to pre-crisis levels and expiration of bank guidance to roll over maturing SME loans are welcome. With financial conditions having normalized, the financial sector support measures can also be unwound without putting the recovery at risk.
48. It is appropriate to now shift the focus from crisis management to the medium-term strategy to sustain growth and enhance the economy's resilience. This strategy should build on lessons from the global crisis. In this context, the authorities' plan for fiscal consolidation over the medium term, aiming to achieve a balanced budget (excluding social security funds) by 2013-14, is a welcome start in light of the aging population and the need to retain fiscal room for counter-cyclical policies. More details on the planned measures to achieve this target would further enhance credibility. A further formalization of the medium-term fiscal framework, including through the introduction of a fiscal rule, would provide an additional anchor for fiscal policy.

49. The global crisis demonstrated how "benign neglect" in monetary policy may have allowed for a buildup of asset price bubbles and excessive leverage in some economies. While overall price stability should remain the BOK's primary objective, it may be appropriate to consider broadening the monetary policy framework to allow for discretionary policy responses in the event of emerging price pressures in asset markets or excessive buildup of leverage, should it be judged to have a bearing on the inflation outlook and/or macroeconomic and financial stability.

50. It is also appropriate to consider how to further upgrade macroeconomic policy and regulatory frameworks to enhance the resilience of the economy during normal times. A key lesson of the global crisis is the need to better internalize macrofinancial linkages and strengthen the coordination process among all the relevant agencies 
charged with financial stability. Financial instability could, for example, be exacerbated by overly accommodative monetary policy settings. At the same time, policy rates may be a blunt tool for addressing financial instability emerging in specific sectors, which may initially require a macro-prudential response. Another key lesson from the global crisis is the need to strengthen supervisory and regulatory frameworks across the world, and we welcome the Korean authorities' preemptive steps in that direction and their readiness to adopt new measures that will emerge from international consensus.

51. Korea's vulnerability to the potentially destabilizing effects of volatile international capital flows remain of concern. The recently introduced foreign currency related measures may reduce banks' external indebtedness and strengthen liquidity management. However, they are not likely to substantially reduce the economy's vulnerability to sudden stops given the welcome commitment to an open capital account. For an export-dependent economy with an open capital account, the best line of defense remains a flexible exchange rate and a sound financial sector.

52. The recent global crisis has exposed the risks of an open economy relying on a single engine of growth. Strengthening domestic sources of growth would reduce Korea's vulnerability to economic downturns elsewhere in the world. In this context, reducing the policy bias towards exports and bolder reforms to increase productivity in the nontradable sector would be welcome. More labor market flexibility and increased social protection would facilitate the reallocation of labor to new growth sectors while minimizing adjustment costs. Continuing efforts to increase labor market participation would also be welcome.

53. It is recommended that the next Article IV consultation take place on the standard 12-month cycle. 
Table 1. Korea: Selected Economic Indicators, 2006-11

Nominal GDP (2009): \$832.3 billion

Main exports (percent of total, 2009): Electronics (33), vessels (12), and road vehicles (6).

GDP per capita (2009): $\$ 17,071$

Unemployment rate (2009): 3.7 percent

FDI (2009): \$1.5 billion

Central government debt (2009): 32.6 percent of GDP

Foreign central government debt (2009): 3.2 percent of total central government debt

\begin{tabular}{|c|c|c|c|c|c|c|}
\hline & \multirow[b]{2}{*}{2006} & \multirow[b]{2}{*}{2007} & \multirow[b]{2}{*}{2008} & \multirow[b]{2}{*}{2009} & \multicolumn{2}{|c|}{ Projections } \\
\hline & & & & & 2010 & 2011 \\
\hline Real GDP (percent change) & 5.2 & 5.1 & 2.3 & 0.2 & 6.1 & 4.5 \\
\hline Total domestic demand & 4.9 & 4.5 & 1.4 & -3.2 & 6.4 & 3.3 \\
\hline Final domestic demand & 4.6 & 4.9 & 0.8 & 0.8 & 3.4 & 2.9 \\
\hline Consumption & 5.1 & 5.1 & 2.0 & 1.2 & 2.6 & 3.3 \\
\hline Gross fixed investment & 3.4 & 4.2 & -1.9 & -0.2 & 5.3 & 1.9 \\
\hline Stock building $1 /$ & 0.3 & -0.3 & 0.6 & -3.8 & 2.7 & 0.4 \\
\hline Net foreign balance $1 /$ & 0.3 & 0.7 & 1.1 & 3.1 & 0.2 & 1.5 \\
\hline Nominal GDP (in trillions of won) & 908.7 & 975.0 & $1,026.5$ & $1,063.1$ & $1,154.1$ & $1,249.7$ \\
\hline \multicolumn{7}{|l|}{ Saving and investment (in percent of GDP) } \\
\hline Gross national saving & 30.2 & 30.0 & 30.6 & 31.0 & 31.7 & 31.4 \\
\hline Gross domestic investment & 29.6 & 29.4 & 31.2 & 25.9 & 29.5 & 28.9 \\
\hline Current account balance & 0.6 & 0.6 & -0.6 & 5.1 & 2.2 & 2.5 \\
\hline \multicolumn{7}{|l|}{ Prices (percent change) } \\
\hline $\mathrm{CPI}$ inflation (end of period) & 2.1 & 3.6 & 4.1 & 2.8 & 3.0 & 3.5 \\
\hline Core inflation (average) & 1.8 & 2.3 & 4.3 & 3.6 & 2.3 & 2.5 \\
\hline GDP deflator & -0.1 & 2.1 & 2.9 & 3.4 & 2.3 & 3.6 \\
\hline Real effective exchange rate & 7.4 & 0.1 & -19.9 & -12.4 & $\ldots$ & $\ldots$ \\
\hline \multicolumn{7}{|l|}{ Trade (percent change) } \\
\hline Export volume & 13.2 & 10.4 & 6.8 & 0.0 & 14.7 & 9.3 \\
\hline Import volume & 10.5 & 9.0 & 0.9 & -7.9 & 16.7 & 7.9 \\
\hline Terms of trade & -6.6 & -2.5 & -14.3 & 8.9 & -2.9 & 0.4 \\
\hline \multicolumn{7}{|l|}{ Consolidated central government (in percent of GDP) } \\
\hline Revenue & 23.1 & 25.0 & 24.4 & 24.0 & 23.7 & 23.5 \\
\hline Expenditure & 21.3 & 21.5 & 23.3 & 25.7 & 22.8 & 22.0 \\
\hline Overall balance & 1.7 & 3.5 & 1.2 & -1.7 & 0.9 & 1.5 \\
\hline Excluding Social Security Funds & -1.2 & 0.4 & -1.5 & -4.1 & -1.4 & -0.8 \\
\hline \multicolumn{7}{|l|}{ Money and credit (end of period) } \\
\hline Overnight call rate $2 /$ & 4.6 & 5.0 & 2.9 & 2.0 & 2.0 & $\ldots$ \\
\hline Three-year AA- corporate bond yield $2 /$ & 5.3 & 6.8 & 7.7 & 5.5 & 4.8 & $\ldots$ \\
\hline $\mathrm{M} 3$ growth (y/y, in percent) $3 /$ & 10.5 & 10.0 & 9.1 & 9.4 & 9.2 & $\ldots$ \\
\hline \multicolumn{7}{|l|}{ Balance of payments (in billions of U.S. dollars) } \\
\hline Exports, f.o.b. & 331.8 & 379.0 & 432.9 & 373.6 & 459.9 & 510.2 \\
\hline Imports, f.o.b. & 303.9 & 350.9 & 427.3 & 317.5 & 409.6 & 446.5 \\
\hline Oil imports & 55.9 & 60.3 & 85.9 & 52.9 & 68.6 & 72.9 \\
\hline Current account balance & 5.4 & 5.9 & -5.8 & 42.7 & 22.4 & 27.4 \\
\hline Gross international reserves (end of period) 4/ & 238.9 & 262.1 & 201.1 & 269.9 & 280.3 & 294.0 \\
\hline In percent of short-term debt (residual maturity & 172.5 & 130.8 & 105.3 & 138.2 & 144.0 & 152.2 \\
\hline \multicolumn{7}{|l|}{ External debt (in billions of U.S. dollars) } \\
\hline Total external debt (end of period) & 260.1 & 383.2 & 377.9 & 401.9 & 402.0 & 400.5 \\
\hline Of which: Short-term (end of period) & 113.7 & 160.2 & 149.9 & 150.0 & 149.1 & 147.7 \\
\hline Total external debt (in percent of GDP) & 27.3 & 36.5 & 40.5 & 48.3 & 40.0 & 36.8 \\
\hline Debt service ratio 5/ & 7.4 & 7.5 & 10.2 & 10.5 & 9.1 & 8.4 \\
\hline
\end{tabular}

Sources: Korean authorities; and IMF staff estimates and projections

1/ Contribution to GDP growth.

2/ Data for 2010 are as of August 2.

3/ Data for 2010 are as of May.

4/ Excluding gold.

5/ Debt service on medium- and long-term debt in percent of exports of goods and services. 
Table 2. Korea: Balance of Payments, 2005-10

(In billions of U.S. dollars, unless otherwise indicated)

\begin{tabular}{|c|c|c|c|c|c|c|}
\hline & 2005 & 2006 & 2007 & 2008 & 2009 & $\begin{array}{r}\text { Projections } \\
2010\end{array}$ \\
\hline Current account balance & 15.0 & 5.4 & 5.9 & -5.8 & 42.7 & 22.4 \\
\hline Trade balance & 32.7 & 27.9 & 28.2 & 5.7 & 56.1 & 50.4 \\
\hline Exports & 289.0 & 331.8 & 379.0 & 432.9 & 373.6 & 459.9 \\
\hline Imports & 256.3 & 303.9 & 350.9 & 427.3 & 317.5 & 409.6 \\
\hline Services & -13.7 & -19.0 & -19.8 & -16.7 & -17.2 & -25.0 \\
\hline Income & -1.6 & 0.5 & 1.0 & 5.9 & 4.6 & -2.4 \\
\hline Current transfers & -2.5 & -4.1 & -3.5 & -0.7 & -0.8 & -0.6 \\
\hline Financial and capital account balance & 7.0 & 18.5 & 7.6 & -49.6 & 26.9 & -11.6 \\
\hline Financial account & 9.3 & 21.6 & 10.0 & -49.7 & 25.7 & -9.1 \\
\hline Portfolio investment, net & -1.7 & -22.7 & -20.6 & -17.2 & 45.1 & 19.4 \\
\hline Direct investment, net & 2.0 & -4.5 & -13.8 & -15.6 & -9.1 & -14.0 \\
\hline Other investment, assets & -2.7 & -7.9 & -16.8 & -13.7 & 0.4 & -7.0 \\
\hline Other investment, liabilities & 11.7 & 56.8 & 61.2 & -3.2 & -10.8 & -7.5 \\
\hline Capital account & -2.3 & -3.1 & -2.4 & 0.1 & 1.2 & -2.5 \\
\hline Net errors and omissions & 0.1 & -1.2 & 2.1 & -0.6 & -0.1 & 0.0 \\
\hline Overall balance & 22.1 & 22.6 & 15.6 & -56.0 & 69.5 & 10.8 \\
\hline Financing & -22.1 & -22.6 & -15.6 & 56.0 & -69.5 & -10.8 \\
\hline \multicolumn{7}{|l|}{ Memorandum items: } \\
\hline Current account balance (in percent of GDP) & 1.8 & 0.6 & 0.6 & -0.6 & 5.1 & 2.2 \\
\hline Trade balance (in percent of GDP) & 3.9 & 2.9 & 2.7 & 0.6 & 6.7 & 5.0 \\
\hline Gross reserves $1 /$ & 210.3 & 238.9 & 262.1 & 201.1 & 269.9 & 280.3 \\
\hline (In months of imports of goods and services) & 8.0 & 7.7 & 7.2 & 4.6 & 8.2 & 6.7 \\
\hline External debt & 187.9 & 260.1 & 383.2 & 377.9 & 401.9 & 402.0 \\
\hline (in percent of GDP) & 22.2 & 27.3 & 36.5 & 40.5 & 48.3 & 40.0 \\
\hline Short-term external debt (inc. trade credits) & 65.9 & 113.7 & 160.2 & 149.9 & 150.0 & 149.1 \\
\hline Nominal GDP & 844.8 & 951.2 & 1049.1 & 933.0 & 832.3 & 1005.9 \\
\hline
\end{tabular}

Sources: Korean authorities; and IMF staff estimates and projections.

1/ Excluding gold. 
Table 3. Korea: Consolidated Central Government Operations, 2005-11

\begin{tabular}{|c|c|c|c|c|c|c|c|}
\hline & \multirow[b]{2}{*}{2005} & \multirow[b]{2}{*}{2006} & \multirow[b]{2}{*}{2007} & \multirow[b]{2}{*}{2008} & \multirow[b]{2}{*}{2009} & \multicolumn{2}{|c|}{ Projections } \\
\hline & & & & & & 2010 & 2011 \\
\hline & \multicolumn{7}{|c|}{ (In trillions of won) } \\
\hline Revenue & 191.4 & 209.6 & 243.6 & 250.7 & 255.3 & 273.0 & 293.6 \\
\hline Tax revenue & 127.5 & 138.0 & 161.5 & 167.3 & 164.5 & 175.7 & 187.4 \\
\hline Social security contributions & 24.9 & 27.3 & 29.7 & 32.9 & 33.9 & 36.8 & 40.6 \\
\hline Nontax and capital revenue & 39.1 & 44.2 & 52.4 & 50.5 & 56.8 & 60.5 & 65.6 \\
\hline Expenditure and net lending & 175.9 & 193.9 & 209.8 & 238.8 & 272.9 & 262.8 & 274.6 \\
\hline Current expenditure 1/ & 148.3 & 161.7 & 169.7 & 196.9 & 209.7 & 210.9 & 218.9 \\
\hline Interest & 10.1 & 12.2 & 13.4 & 14.4 & 16.0 & 16.3 & 19.9 \\
\hline Noninterest & 138.2 & 149.5 & 156.2 & 182.5 & 193.7 & 194.6 & 199.0 \\
\hline Capital expenditure & 24.6 & 26.5 & 33.0 & 36.5 & 45.1 & 45.9 & 49.7 \\
\hline Net lending & 3.0 & 5.7 & 7.1 & 5.5 & 18.0 & 5.9 & 5.9 \\
\hline Overall balance & 15.5 & 15.6 & 33.8 & 11.9 & -17.6 & 10.2 & 19.0 \\
\hline Of which: Social Security Fund balance & 23.6 & 26.4 & 30.2 & 27.5 & 25.6 & 26.1 & 29.5 \\
\hline \multirow[t]{2}{*}{ Excluding Social Security Funds } & -8.1 & -10.8 & 3.6 & -15.7 & -43.2 & -15.9 & -10.6 \\
\hline & \multicolumn{7}{|c|}{ (In percent of GDP) } \\
\hline Revenue & 22.1 & 23.1 & 25.0 & 24.4 & 24.0 & 23.7 & 23.5 \\
\hline Tax revenue & 14.7 & 15.2 & 16.6 & 16.3 & 15.5 & 15.2 & 15.0 \\
\hline Social security contributions & 2.9 & 3.0 & 3.1 & 3.2 & 3.2 & 3.2 & 3.2 \\
\hline Nontax and capital revenue & 4.5 & 4.9 & 5.4 & 4.9 & 5.3 & 5.2 & 5.2 \\
\hline Expenditure and net lending & 20.3 & 21.3 & 21.5 & 23.3 & 25.7 & 22.8 & 22.0 \\
\hline Current expenditure & 17.1 & 17.8 & 17.4 & 19.2 & 19.7 & 18.3 & 17.5 \\
\hline Interest & 1.2 & 1.3 & 1.4 & 1.4 & 1.5 & 1.4 & 1.6 \\
\hline Noninterest & 16.0 & 16.5 & 16.0 & 17.8 & 18.2 & 16.9 & 15.9 \\
\hline Capital expenditure & 2.8 & 2.9 & 3.4 & 3.6 & 4.2 & 4.0 & 4.0 \\
\hline Net lending & 0.3 & 0.6 & 0.7 & 0.5 & 1.7 & 0.5 & 0.5 \\
\hline Overall balance & 1.8 & 1.7 & 3.5 & 1.2 & -1.7 & 0.9 & 1.5 \\
\hline Of which: Social Security Fund balance & 2.7 & 2.9 & 3.1 & 2.7 & 2.4 & 2.3 & 2.4 \\
\hline Excluding Social Security Funds & -0.9 & -1.2 & 0.4 & -1.5 & -4.1 & -1.4 & -0.8 \\
\hline Overall structural balance & 1.9 & 1.7 & 3.5 & 1.3 & -0.9 & 1.0 & 1.5 \\
\hline Primary balance & 3.0 & 3.1 & 4.8 & 2.6 & -0.2 & 2.3 & 3.1 \\
\hline \multicolumn{8}{|l|}{ Memorandum item: } \\
\hline Nominal GDP (trillion won) & 865.2 & 908.7 & 975.0 & $1,026.5$ & $1,063.1$ & $1,154.1$ & 1249.7 \\
\hline
\end{tabular}

Sources: Ministry of Planning and Budget; and IMF staff estimates and projections.

1/ The conversion of KDIC and KAMCO bonds is excluded, amounting to W 13 trillion in 2003, and W 12 trillion annually until 2006. 
Table 4. Korea: Medium-Term Projections, 2007-15

\begin{tabular}{|c|c|c|c|c|c|c|c|c|c|}
\hline & \multirow[b]{2}{*}{2007} & \multirow[b]{2}{*}{2008} & \multirow[b]{2}{*}{2009} & \multicolumn{6}{|c|}{ Projections } \\
\hline & & & & 2010 & 2011 & 2012 & 2013 & 2014 & 2015 \\
\hline Real GDP (percent change) & 5.1 & 2.3 & 0.2 & 6.1 & 4.5 & 4.2 & 4.1 & 4.0 & 4.0 \\
\hline Total domestic demand & 4.5 & 1.4 & -3.2 & 6.4 & 3.3 & 3.7 & 3.9 & 3.9 & 3.9 \\
\hline Final domestic demand & 4.9 & 0.8 & 0.8 & 3.4 & 2.9 & 3.8 & 3.9 & 3.9 & 3.9 \\
\hline Consumption & 5.1 & 2.0 & 1.2 & 2.6 & 3.3 & 3.8 & 3.8 & 3.8 & 3.8 \\
\hline Gross fixed investment & 4.2 & -1.9 & -0.2 & 5.3 & 1.9 & 3.7 & 4.3 & 4.3 & 4.3 \\
\hline Stock building $1 /$ & -0.3 & 0.6 & -3.8 & 2.7 & 0.4 & 0.0 & 0.0 & 0.0 & 0.0 \\
\hline Net foreign balance $1 /$ & 0.7 & 1.1 & 3.1 & 0.2 & 1.5 & 0.7 & 0.5 & 0.4 & 0.4 \\
\hline \multicolumn{10}{|l|}{ Prices, period average (percent change) } \\
\hline Consumer price & 2.5 & 4.7 & 2.8 & 3.1 & 3.4 & 3.0 & 3.0 & 3.0 & 3.0 \\
\hline GDP deflator & 2.1 & 2.9 & 3.4 & 2.3 & 3.6 & 2.8 & 2.1 & 2.9 & 3.2 \\
\hline \multicolumn{10}{|l|}{ Savings and investment (percent of GDP) } \\
\hline Gross national savings & 30.0 & 30.6 & 31.0 & 31.7 & 31.4 & 31.1 & 31.4 & 31.3 & 31.0 \\
\hline Gross domestic investment & 29.4 & 31.2 & 25.9 & 29.5 & 28.9 & 28.8 & 29.1 & 29.2 & 28.9 \\
\hline Current account balance & 0.6 & -0.6 & 5.1 & 2.2 & 2.5 & 2.3 & 2.3 & 2.0 & 2.0 \\
\hline \multicolumn{10}{|l|}{ Consolidated central government (in percent of GDP) } \\
\hline Revenue & 25.0 & 24.4 & 24.0 & 23.7 & 23.5 & 23.7 & 24.0 & 24.1 & 24.1 \\
\hline Expenditure & 21.5 & 23.3 & 25.7 & 22.8 & 22.0 & 21.8 & 21.8 & 21.7 & 21.8 \\
\hline Balance 2/ & 3.5 & 1.2 & -1.7 & 0.9 & 1.5 & 1.9 & 2.2 & 2.4 & 2.4 \\
\hline Excluding Social Security Funds & 0.4 & -1.5 & -4.1 & -1.4 & -0.8 & -0.4 & -0.1 & 0.0 & 0.0 \\
\hline Debt, domestic plus external $3 /$ & 29.7 & 29.0 & 32.6 & 32.1 & 30.5 & 28.8 & 27.3 & 25.4 & 23.7 \\
\hline Government guaranteed restructuring bonds 4 / & 3.4 & 2.7 & 4.6 & 3.1 & 2.6 & 2.1 & 1.7 & 1.3 & 1.0 \\
\hline \multicolumn{10}{|l|}{ Trade (percent change) } \\
\hline Merchandise exports & 14.2 & 14.2 & -13.7 & 23.1 & 10.9 & 9.9 & 9.1 & 9.2 & 9.1 \\
\hline Volumes $4 /$ & 10.4 & 6.8 & 0.0 & 14.7 & 9.3 & 9.5 & 9.6 & 9.1 & 9.1 \\
\hline Merchandise imports & 15.4 & 21.8 & -25.7 & 29.0 & 9.0 & 11.2 & 11.3 & 10.8 & 9.5 \\
\hline Volumes $4 /$ & 9.0 & 0.9 & -7.9 & 16.7 & 7.9 & 9.6 & 10.4 & 9.9 & 9.9 \\
\hline Terms of trade & -2.5 & -14.3 & 8.9 & -2.9 & 0.4 & -1.0 & -1.2 & -0.7 & 0.4 \\
\hline \multicolumn{10}{|l|}{ Balance of payments (billions of U.S. dollars) } \\
\hline Current account & 5.9 & -5.8 & 42.7 & 22.4 & 27.4 & 26.6 & 28.6 & 26.8 & 28.8 \\
\hline Trade balance & 28.2 & 5.7 & 56.1 & 50.4 & 63.6 & 64.5 & 59.5 & 56.3 & 59.3 \\
\hline Merchandise exports & 379.0 & 432.9 & 373.6 & 459.9 & 510.2 & 560.9 & 612.0 & 668.5 & 729.6 \\
\hline Merchandise imports & 350.9 & 427.3 & 317.5 & 409.6 & 446.5 & 496.5 & 552.4 & 612.3 & 670.3 \\
\hline \multicolumn{10}{|l|}{ External debt } \\
\hline In billions of U.S. dollars 5 / & 383.2 & 377.9 & 401.9 & 402.0 & 400.5 & 399.3 & 396.5 & 391.9 & 385.3 \\
\hline (as percent of GDP) & 36.5 & 40.5 & 48.3 & 40.0 & 36.8 & 34.4 & 32.2 & 29.8 & 27.2 \\
\hline Debt service ratio $6 /$ & 7.5 & 10.2 & 10.5 & 9.1 & 8.4 & 8.6 & 8.9 & 8.4 & 7.6 \\
\hline \multicolumn{10}{|l|}{ Memorandum items: } \\
\hline Nominal GDP (trillion won) & 975 & 1,026 & 1,063 & 1,154 & 1,250 & 1,339 & 1,424 & 1,523 & 1,635 \\
\hline Per capita GDP (U.S. dollars) & 21,651 & 19,195 & 17,071 & 20,566 & 22,173 & 23,585 & 24,917 & 26,596 & 28,486 \\
\hline Output gap (percent of potential GDP) & 0.0 & -0.7 & -3.1 & -0.5 & 0.3 & 0.4 & 0.4 & 0.2 & 0.0 \\
\hline
\end{tabular}

Sources: Korean authorities; and IMF staff estimates and projections.

1/ Contribution to GDP growth.

2/ Excludes privatization receipts and conversion of KDIC/KAMCO bonds into treasury bonds.

3/ During 2003-06, W 49 trillion in government guaranteed KDIC/KAMCO bonds have been converted into treasury bonds. 4/ Customs clearance basis.

5/ Includes IMF and offshore borrowing of domestic financial institutions and debt contracted by their overseas branches.

6/ Debt service on medium- and long-term debt in percent of exports of goods and services. 
Table 5. Korea: Financial Soundness Indicators, 2003-09

\begin{tabular}{|c|c|c|c|c|c|c|c|}
\hline & 2003 & 2004 & 2005 & 2006 & 2007 & 2008 & 2009 \\
\hline Financial Sector & \multicolumn{7}{|c|}{ (In percent) } \\
\hline Total loans/GDP & 92.4 & 88.8 & 91.9 & 102.4 & 110.1 & 125.5 & 121.0 \\
\hline Commercial banks & 65.1 & 61.9 & 63.3 & 71.0 & 75.2 & 83.3 & 79.3 \\
\hline Other financial institutions & 27.3 & 26.8 & 28.6 & 31.3 & 34.9 & 42.2 & 41.7 \\
\hline Bank loans & \multicolumn{7}{|c|}{ (Year-on-year percent change) } \\
\hline SMEs & 17.9 & 3.0 & 4.7 & 17.7 & 22.5 & 13.2 & 4.8 \\
\hline Households & 13.8 & 8.9 & 10.7 & 13.4 & 5.1 & 6.9 & 5.2 \\
\hline Large companies & -13.3 & -11.1 & 15.9 & -4.6 & 32.9 & 60.0 & -6.4 \\
\hline Banks 1/ & \multicolumn{7}{|c|}{ (In percent) } \\
\hline Capital adequacy ratio & 11.2 & 12.1 & 13.0 & 12.8 & 12.3 & 12.3 & 14.4 \\
\hline Tier 1 capital ratio & 7.0 & 8.0 & 9.3 & 9.2 & 9.0 & 8.8 & 10.9 \\
\hline Return on assets & 0.2 & 0.9 & 1.3 & 1.1 & 1.1 & 0.5 & 0.4 \\
\hline Net interest margin & 2.6 & 2.6 & 2.8 & 2.6 & 2.4 & 2.3 & 2.0 \\
\hline Substandard or below loans & \multicolumn{7}{|c|}{ (In percent of total loans) } \\
\hline Commercial banks & 2.8 & 2.0 & 1.3 & 0.9 & 0.7 & 1.2 & 1.2 \\
\hline Specialized banks & 2.4 & 1.7 & 1.1 & 0.7 & 0.7 & 1.1 & 1.4 \\
\hline Mutual savings banks & 11.8 & 13.0 & 13.8 & 10.5 & 8.8 & 9.1 & 9.2 \\
\hline Credit unions & 6.3 & 6.0 & 5.4 & 4.5 & 3.8 & 3.5 & 3.7 \\
\hline Corporate Sector & \multicolumn{7}{|c|}{ (In percent) } \\
\hline Corporate debt/GDP 2/ & 109.1 & 104.9 & 104.3 & 112.0 & 117.5 & 144.1 & 139.1 \\
\hline Delinquency ratio (domestic commercial bank k & 2.1 & 2.1 & 1.5 & 1.2 & 1.0 & 1.6 & 1.0 \\
\hline \multicolumn{8}{|l|}{ Debt ratio to: } \\
\hline Equity & 123.4 & 104.2 & 100.9 & 98.9 & 108.0 & 124.5 & $\ldots$ \\
\hline Total assets & 28.3 & 24.0 & 22.9 & 22.4 & 25.1 & 26.4 & $\ldots$ \\
\hline Sales & 26.6 & 20.7 & 19.9 & 19.9 & 23.6 & 24.5 & $\ldots$ \\
\hline Interest coverage ratio $3 /$ & 367.1 & 575.8 & 525.4 & 439.3 & 425.7 & 408.7 & $\ldots$ \\
\hline Current assets/current liabilities & 109.8 & 117.0 & 121.4 & 120.5 & 119.6 & 112.3 & $\ldots$ \\
\hline Operating income/sales & 6.9 & 7.6 & 6.1 & 5.3 & 5.8 & 5.9 & $\ldots$ \\
\hline Financial expenses/sales & -1.9 & -1.3 & -1.2 & -1.2 & -1.4 & -1.4 & $\ldots$ \\
\hline Ordinary income/sales & 4.7 & 7.8 & 6.6 & 5.8 & 6.1 & 3.1 & ... \\
\hline Household Sector & \multicolumn{7}{|c|}{ (In percent of GDP) } \\
\hline Household credit & 59.8 & 60.1 & 62.6 & 62.7 & 62.5 & 68.7 & 66.7 \\
\hline Of which: Commercial banks & 33.9 & 35.0 & 36.7 & 37.3 & 36.0 & 38.8 & 37.2 \\
\hline Delinquency ratio (all bank loans) & \multicolumn{7}{|c|}{ (In percent) } \\
\hline Households & 1.8 & 1.7 & 1.1 & 0.7 & 0.6 & 0.6 & 0.5 \\
\hline Credit card 4/ & 7.8 & 4.1 & 2.2 & 1.7 & 1.3 & 1.8 & 1.4 \\
\hline Housing prices, percent change & 5.7 & -2.1 & 4.0 & 11.6 & 3.1 & 3.1 & 1.5 \\
\hline Of which: Seoul & 6.8 & -1.4 & 6.3 & 18.9 & 5.4 & 5.0 & 2.7 \\
\hline
\end{tabular}

Sources: Bank of Korea; Financial Supervisory Service; and CEIC Data Company Ltd.

$1 /$ Includes nationwide commercial banks, regional banks, and specialized banks.

2/ Includes nonfinancial corporations.

3/ Operating income to gross interest payments. Operating income treats depreciation as an expense, so this ratio is lower than calculations using earnings before interest, taxes, and depreciation allowance (EBITDA).

4/ Over one month. 
Table 6. Korea: Indicators of Financial and External Vulnerability, 2005-10

(In percent of GDP, unless otherwise indicated)

\begin{tabular}{|c|c|c|c|c|c|c|c|}
\hline & \multirow[b]{2}{*}{2005} & \multirow[b]{2}{*}{2006} & \multirow[b]{2}{*}{2007} & \multirow[b]{2}{*}{2008} & \multirow[b]{2}{*}{2009} & \multicolumn{2}{|c|}{2010} \\
\hline & & & & & & & Date \\
\hline \multicolumn{8}{|l|}{ Financial indicators } \\
\hline Consolidated central government debt $1 /$ & 33.9 & 34.1 & 33.0 & 31.8 & 35.4 & 35.2 & Proj \\
\hline Broad money (M3, percent change, 12-month basis) & 7.4 & 10.5 & 10.0 & 9.1 & 9.4 & 9.2 & May-10 \\
\hline Private sector credit (Dep. Corp. survey, percent change, 12-month basis) & 8.5 & 16.2 & 14.7 & 16.8 & 2.6 & 4.1 & May-10 \\
\hline One-month call borrowing rate & 3.8 & 4.6 & 5.0 & 2.9 & 2.0 & 2.0 & Jul-10 \\
\hline One-month call borrowing rate (real) & 1.1 & 2.5 & 1.4 & -1.2 & -0.8 & -0.6 & Jul-10 \\
\hline \multicolumn{8}{|l|}{ External indicators } \\
\hline Exports (percent change, 12-month basis in US\$) & 12.1 & 14.8 & 14.2 & 14.2 & -13.7 & 31.7 & Jun-10 \\
\hline Imports (percent change, 12-month basis in US\$) & 16.4 & 18.6 & 15.4 & 21.8 & -25.7 & 41.1 & Jun-10 \\
\hline Terms of trade (percent change, 12-month basis) & -7.3 & -6.6 & -2.5 & -14.3 & 8.9 & -6.1 & May-10 \\
\hline Current account balance (projection for full year) & 1.8 & 0.6 & 0.6 & -0.6 & 5.1 & 2.2 & Proj \\
\hline Capital and financial account balance (projection for full year) & 0.8 & 1.9 & 0.7 & -5.3 & 3.2 & -1.2 & Proj \\
\hline Of which: Inward portfolio investment (equity, debt securities etc.) & 1.1 & 0.0 & 2.3 & -10.3 & -0.1 & 2.6 & Proj \\
\hline Other investment (loans, trade credits etc.) & 1.1 & 5.9 & 5.8 & -0.4 & -1.3 & -0.8 & Proj \\
\hline Inward foreign direct investment in the form of debt or loans & 0.1 & 0.1 & 0.1 & 0.2 & 0.1 & $\ldots$ & ... \\
\hline Gross official reserves (in US\$ billion) 2/ & 210.3 & 238.9 & 262.1 & 201.1 & 269.9 & 274.2 & Jun-10 \\
\hline Central bank short-term foreign liabilities (in US\$ billion) & 2.2 & 3.9 & 9.6 & 18.3 & 12.8 & $\ldots$ & ... \\
\hline Short-term foreign liabilities of the financial sector (in US\$ billion) & 32.2 & 40.4 & 58.9 & 59.0 & 65.7 & $\ldots$ & ... \\
\hline Official reserves in months of imports GS (projection for full year) & 8.0 & 7.7 & 7.2 & 4.6 & 8.2 & 6.7 & Proj \\
\hline Broad money $(\mathrm{M} 3)$ to reserves & 6.5 & 6.9 & 6.9 & 7.3 & 6.4 & 6.5 & May-10 \\
\hline Reserves to total short-term external debt (in percent) $3 /$ & 239.6 & 172.5 & 130.8 & 105.3 & 138.2 & 144.0 & Proj \\
\hline Total external debt & 22.2 & 27.3 & 36.5 & 40.5 & 48.3 & 40.0 & Proj \\
\hline Of which: Public sector debt & 1.0 & 1.1 & 3.0 & 2.3 & 3.3 & $\ldots$ & ... \\
\hline Of which: Short-term debt & 7.8 & 12.0 & 15.3 & 16.1 & 18.0 & 14.8 & Proj. \\
\hline Total external debt to exports GS (in percent) & 56.2 & 68.1 & 86.6 & 74.1 & 93.0 & 76.5 & Proj \\
\hline External interest payments to exports GS (in percent) & 1.4 & 1.7 & 1.9 & 2.3 & 1.0 & 0.5 & Proj \\
\hline External amortization payments to exports GS (in percent) & 6.6 & 5.7 & 5.6 & 7.9 & 9.5 & 8.6 & Proj \\
\hline Exchange rate (per US\$, period average) & 1,024 & 955 & 929 & 1,100 & 1,277 & 1,172 & Aug 2, 10 \\
\hline REER appreciation $(+)$ (12-month basis) & 12.2 & 7.4 & 0.1 & -17.9 & -12.0 & 5.3 & Jun-10 \\
\hline \multicolumn{8}{|l|}{ Financial market indicators } \\
\hline Stock market index (KOSPI) & 1379 & 1434 & 1897 & 1124 & 1683 & 1782 & Aug 2, 10 \\
\hline Stock market index (KOSPI, percent change, 12-month basis) & 54.3 & 4.0 & 32.3 & -40.7 & 49.7 & 13.9 & Aug 2, 10 \\
\hline Foreign currency debt rating (Moody's/S\&P) & $\mathrm{A} 3 / \mathrm{A}$ & $\mathrm{A} 3 / \mathrm{A}$ & $\mathrm{A} 2 / \mathrm{A}$ & $\mathrm{A} 2 / \mathrm{A}$ & $\mathrm{A} 2 / \mathrm{A}$ & $\mathrm{A} 1 / \mathrm{A}$ & Aug 2, 10 \\
\hline
\end{tabular}

Sources: Korean authorities; private market sources; and IMF staff estimates and projections.

1/ Including government guaranteed restructuring bonds issued by KDIC and KAMCO.

2/ Excluding gold.

3/ Short-term debt measured on a residual maturity basis. 


\section{INTERNATIONAL MONETARY FUND}

\section{REPUBLIC OF KOREA}

\section{Staff Report for the 2010 Article IV Consultation-Informational Annex}

Prepared by the Asia and Pacific Department

August 3, 2010

Contents

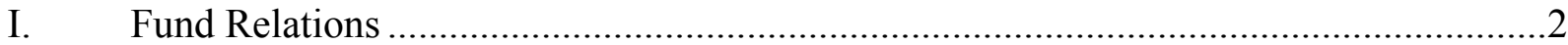

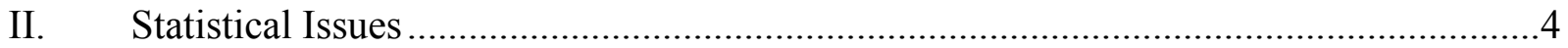




\section{ANNEX I: KoREA-Fund RELATIONS}

(As of June 30, 2010)

I. Membership Status: Joined August 26, 1955; Article VIII

II. General Resources Account:

Quota

SDR Million

2,927.3

\% Quota

Fund Holdings of Currency

2,298.9

100.0

Reserve Position in Fund

628.4

78.53

21.47

III. SDR Department:

SDR Million

Net cumulative allocation

$2,404.5$

$\%$ Allocation

100.00

Holdings

$2,297.9$

95.57

IV. Outstanding Purchases and Loans: None

V. Latest Financial Arrangements:

$\begin{array}{lcccc}\text { Type } & \begin{array}{c}\text { Approval } \\ \text { Date }\end{array} & \begin{array}{c}\text { Expiration } \\ \text { Date }\end{array} & \begin{array}{c}\text { Amount Approved } \\ \text { (SDR Million) }\end{array} & \begin{array}{c}\text { Amount Drawn } \\ \text { (SDR Million) }\end{array} \\ { } } & 12 / 04 / 1997 & 12 / 03 / 2000 & 15,500.00 & 14,412.50 \\ \text { Of which: SRF } & 12 / 18 / 1997 & 12 / 17 / 1998 & 9,950.00 & 9,950.00 \\ \text { Stand-by } & 07 / 12 / 1985 & 03 / 10 / 1987 & 280.00 & 160.00 \\ \text { Stand-by } & 07 / 08 / 1983 & 03 / 31 / 1985 & 575.78 & 575.78\end{array}$

VI. Projected Obligations to the Fund

(SDR million; based on existing use of resources and present holdings of SDRs):

$\begin{array}{lccccc} & \underline{2009} & \underline{2010} & \underline{2011} & \underline{2012} & \underline{2013} \\ \text { Principal } & & & & & \\ \text { Charges/Interest } & 0.04 & 0.09 & 0.31 & 0.31 & 0.31 \\ \text { Total } & 0.04 & 0.09 & 0.31 & 0.31 & 0.31\end{array}$

\section{Exchange Rate Arrangement:}

Korea's exchange rate system is classified as "floating." Previously, the exchange rate against the U.S. dollar was allowed to float only within specified margins around the previous day's weighted average exchange rate in the interbank market. The margins were widened five times between March 1990 and November 1997 (most recently to +/-10 percent), and on December 16, 1997 were eliminated altogether. On July 19, 2010, the exchange rate was W 1,216.6=US\$1. Korea maintains exchange restrictions for security reasons, in accordance with UN Security Council Resolutions, which have been notified to the Fund under the procedures set forth in Executive Board Decision 144-(52/51).

\section{Last Article IV Consultation:}

Korea is on a 12-month consultation cycle. Staff discussions for the 2009 Article IV consultation were conducted on a mission to Seoul during June 25-July 7, 2009. The Article IV consultation was concluded by the Executive Board on August 7, 2009. In addition, a staff visit took place during December 2-8, 2009. 


\section{FSAP and ROSC Participation:}

MCM: The final FSAP mission was conducted during October 2002. The mission completed the FSAP by assessing the short-term vulnerability of the financial sector to macroeconomic and sectoral shocks and analyzing overall financial sector soundness and developmental challenges, including issues arising from the draft standards assessments. A follow-up technical assistance mission on the supervision of derivatives markets was held in Seoul during January 9-20, 2003. The Financial System Stability Assessment report has been published (Country Report No. 03/81) and is available on the web through the following link: http://www.imf.org/external/np/fsap/fsap.asp.

FAD: Discussions on fiscal transparency were held in Seoul during June 2000, and a report was drafted and finalized in November 2000, with input from APD staff. The report has been published and is available on the web through the following link: http://www.imf.org/external/np/rosc/kor/fiscal.htm.

STA: Discussions on Korea's data dissemination practices against the IMF's Special Data Dissemination Standard (SDDS) were held in Seoul during December 2009, and a report was drafted and finalized in July 2010. The report has been published and is available on the web through the link: http://www.imf.org/external/pubs/ft/scr/2010/cr10229.pdf

\section{Technical Assistance:}

FAD: A technical assistance mission visited Seoul during January 8-19, 2001 to evaluate current practices in budgeting and public expenditure management and to provide advice on setting up a medium-term fiscal framework. A mission visited Seoul during August 31-September 16, 2005 to provide technical assistance on the reform of tax policy and administration.

MCM: Technical assistance missions visited Seoul to provide advice on financial holding company supervision and derivatives regulation during December 8-17, 2008, on measures to deepen the money market during December 4-14, 2007, on strengthening the debt management function and further development of the government securities market during September 20-October 2, 2006, on the reform and development of the foreign exchange market during March 30-April 13, 2006, and on macroprudential and derivatives supervision during October 27-November 7, 2005.

STA: Technical assistance missions visited Seoul during March 29-April 12, 2000 to provide advice on balance of payments and external debt statistics, with a view toward improving the recording of financial derivatives and developing an international investment position statement, and during November 28-December 11, 2007 on the GFSM 2001 framework.

\section{Resident Representative:}

The resident representative office in Seoul was opened in March 1998 and was closed in September 2008. 


\section{ANNEX II: KOREA-STATISTICAL ISSUES APPENDIX}

As of July 15, 2010

\section{Assessment of Data Adequacy for Surveillance}

General: Data provision is adequate for surveillance.

National Accounts: The overall structure of the national accounts follows the recommendations of the 1993 System of National Accounts. Chain-linked (reference year 2005) and nominal GDP estimates are compiled using the production and expenditure approaches; nominal GDP estimates are also compiled using the income approach. After the revision to reference year 2005, the estimation method for expenditure components has been altered from the commodity flow method to the direct estimation method, in which each expenditure component is measured directly. The size of the informal sector has not been measured. Improved methods are required to adjust quarterly (seasonally-unadjusted) GDP estimates to agree with annual (benchmark) GDP estimates.

Consumer Price Index: The Consumer Price Index (CPI) covers 38 urban areas (about 80 percent of the urban population), but excludes farm and fishing households. The CPI could be further improved by extending coverage to rural areas. The consumption basket is updated only every five years; currently, expenditure weights are derived from the 2005 Family Income and Expenditure Survey and are in need of updating. The geometric mean of price changes should be used as a suitable alternative to the ratio of arithmetic means of prices.

Producer Price Index: The Producer Price Index (PPI) covers all domestic industrial activities and a large segment of service activity. It excludes exported products, however, because the Export Price Indexes are compiled separately in Korea. The weights are based on 2005 revenue shares and are in need of updating. The PPI could be improved by making more use of imputing missing prices using the prices of similar commodities, rather than carrying forward the last reported price. Although an arithmetic mean of price relatives is currently used rather than a geometric mean, a supplementary index is also compiled using a geometric mean. However, the headline PPI should be changed to the one based on a geometric mean at the elementary level. The PPI classification by activity conforms to the KSIC, which is itself based on the International Standard Industrial Classification (ISIC)--with slight modifications only to reflect local considerations. The Korean commodity classification used for the PPI does not conform to the Central Product Classification (CPC) and one based on the CPC should be adopted as soon as possible.

Government Finance Statistics: Two sets of government finance statistics (GFS) are compiled for the central government, one using national definitions and the other using internationally recognized standards. Concepts and definitions used in the latter still follow the recommendations of the Manual on Government Finance Statistics 1986. The data cover the budgetary units of the central government and certain extra-budgetary funds owned or managed by budgetary units. These statistics are produced by the Digital Budget and Accounting System (D-Brain), which integrates the preparation of budget data, accounting reports, and the generation of fiscal statistics on a monthly basis. The D-Brain provides for automatic crosschecks at different levels of the compilation process. The 2009 ROSC indicated that while compilation practices are generally sound, some room for improvement of the accessibility and timeliness of data and metadata existed. Following the 2009 ROSC, the Korean authorities resumed reporting consolidated GFS data on the general government for publication in the Government Finance Statistics Yearbook (GFSY) and the International Financial Statistics (IFS). The last year for which GFS for the consolidated general government were reported for publication in the GFSY and the IFS is 2007, while data for the central government were reported for 2008. The timeliness of general government data does not comply with SDDS requirements, mainly due to the lack in timeliness on local government source data. During the 2009 ROSC, the authorities also agreed to improve national dissemination practices and initiated work on improving national websites. 
The authorities have announced an ambitious program to implement reporting according to Government Finance Statics Manual 2001 by 2012. In recent developments, the authorities requested technical assistance with implementing these reporting requirements.

Financial Sector Data: Monetary and financial statistics compiled by the Bank of Korea (BOK) broadly follow the IMF's Monetary and Financial Statistical Manual 2000. Data relating to foreign assets and foreign liabilities are affected by the BOK practice of valuing its financial assets and liabilities at book value (rather than at market value) and revaluing its foreign currency-denominated assets and liabilities twice yearly (rather than on a monthly basis). The BOK is in discussion with STA about reporting monetary and financial statistics using Standardized Report Forms (SRFs) and drafting related notes for publication in International Financial Statistics. The BOK anticipates providing monetary and financial data via SRFs within this calendar year.

Korea has participated in the regular reporting of Financial Soundness Indicators (FSIs) to the IMF for dissemination on its website. FSI data and metadata are available to the public through the IMF's website at: http://fsi/FSIHome.aspx\#Country.

External Sector Statistics: Korea follows the Balance of Payments Manual, fifth Edition (BPM5) framework for the compilation of the external sector statistics, although with a few deviations; the scope of the transactions of enterprises through accounts held abroad and of reinvested earnings is partial; trade credits with affiliated entities are recorded under other investment; and income transactions are recorded on a cash flow basis. Based on latest information from the authorities, improved reinvested earnings data are to be disseminated by no later than 2012 . Since January 2010, short-term loans to affiliated entities are classified in direct investment.

The quality of the quarterly external debt statistics has greatly improved. In early 2007, the BOK switched from annual to quarterly reporting of the International Investment Position. Data dissemination on international reserves and foreign currency liquidity generally meets the SDDS specifications. Since April 2006, the authorities have disseminated foreign reserves data on a monthly basis rather than twice a month, as had been done since 1997.

The BOK has plans to migrate to the Balance of Payments and International Investment Position Manual, sixth edition (BPM6); the authorities have already assessed the resources and institutional arrangements for the implementation.

Korea reports balance of payments and IIP data for IFS (quarterly data) and Balance of Payments Statistics Yearbook (annual data) publications.

\section{Data Standards and Quality}

Subscriber to the Fund's Special Data Dissemination Standard (SDDS) since September 1996. Uses SDDS flexibility option on the timeliness of the general government operations and analytical accounts of the banking sector data. Korea is also availing itself of an as relevant flexibility option for the coverage of exchange rates.

A Data ROSC reassessment was published in July 2010. 


\section{Korea-Table of Common Indicators Required for Surveillance}

(As of July 19, 2010)

\begin{tabular}{|c|c|c|c|c|c|c|c|}
\hline & \multirow{2}{*}{$\begin{array}{c}\text { Date of } \\
\text { Latest } \\
\text { Observation }\end{array}$} & \multirow{2}{*}{$\begin{array}{c}\text { Date } \\
\text { Received }\end{array}$} & \multirow{2}{*}{$\begin{array}{c}\text { Frequency } \\
\text { of } \\
\text { Data }^{7}\end{array}$} & \multirow{2}{*}{$\begin{array}{l}\begin{array}{c}\text { Frequency } \\
\text { of } \\
\text { Reporting }\end{array} \\
{ }^{7}\end{array}$} & \multirow{2}{*}{$\begin{array}{l}\text { Frequency } \\
\text { of } \\
\text { Publication }\end{array}$} & \multicolumn{2}{|c|}{ Memo Items: } \\
\hline & & & & & & $\begin{array}{l}\text { Data Quality - } \\
\text { Methodological } \\
\text { Soundness }^{8}\end{array}$ & $\begin{array}{l}\text { Data Quality - } \\
\text { Accuracy and } \\
\text { Reliability } \\
9\end{array}$ \\
\hline Exchange Rates & $7 / 19 / 2010$ & 7/19/2010 & D & D & D & & \\
\hline $\begin{array}{l}\text { International Reserve Assets and } \\
\text { Reserve Liabilities of the Monetary } \\
\text { Authorities }{ }^{1}\end{array}$ & June 2010 & Jul. 2010 & M & M & M & & \\
\hline Reserve/Base Money & June 2010 & Jul. 2010 & M & M & M & O, O, O, LO & $\mathrm{O}, \mathrm{O}, \mathrm{O}, \mathrm{O}, \mathrm{O}$ \\
\hline Broad Money & May 2010 & Jul. 2010 & M & M & M & & \\
\hline Central Bank Balance Sheet & May 2010 & Jul. 2010 & M & M & M & & \\
\hline $\begin{array}{l}\text { Consolidated Balance Sheet of the } \\
\text { Banking System }\end{array}$ & May 2010 & Jul. 2010 & M & M & M & & \\
\hline Interest Rates ${ }^{2}$ & $7 / 19 / 2010$ & $7 / 19 / 2010$ & $\mathrm{D}$ & $\mathrm{D}$ & $\mathrm{D}$ & & \\
\hline Consumer Price Index & June 2010 & Jul. 2010 & M & M & M & $\mathrm{O}, \mathrm{O}, \mathrm{O}, \mathrm{O}$ & $\mathrm{O}, \mathrm{O}, \mathrm{LO}, \mathrm{O}, \mathrm{O}$ \\
\hline $\begin{array}{l}\text { Revenue, Expenditure, Balance and } \\
\text { Composition of Financing }{ }^{3} \text { - General } \\
\text { Government }{ }^{4}\end{array}$ & NA & NA & NA & NA & NA & $\mathrm{O}, \mathrm{O}, \mathrm{O}, \mathrm{O}$ & $\begin{array}{l}\mathrm{O}, \mathrm{O}, \mathrm{N} / \mathrm{A}, \mathrm{O} \\
\mathrm{NA}\end{array}$ \\
\hline $\begin{array}{l}\text { Revenue, Expenditure, Balance and } \\
\text { Composition of Financing }{ }^{3} \text { - Central } \\
\text { Government }\end{array}$ & May 2010 & Jul. 2010 & M & M & M & & \\
\hline $\begin{array}{l}\text { Stocks of Central Government and } \\
\text { Central Government-Guaranteed } \\
\text { Debt }{ }^{5}\end{array}$ & Q4 2009 & May 2010 & Q & Q & Q & & \\
\hline External Current Account Balance & May 2010 & June 2010 & M & M & M & O, LO, LO, LO & $\mathrm{O}, \mathrm{O}, \mathrm{O}, \mathrm{O}, \mathrm{O}$ \\
\hline $\begin{array}{l}\text { Exports and Imports of Goods and } \\
\text { Services }\end{array}$ & May 2010 & June 2010 & M & M & M & & \\
\hline GDP/GNP & Q1 2010 & $\begin{array}{l}\text { Jun. } \\
2010\end{array}$ & Q & Q & Q & $\mathrm{O}, \mathrm{O}, \mathrm{O}, \mathrm{O}$ & O, O, LO, O, LO \\
\hline Gross External Debt & Q1 2010 & Jun. 2010 & Q & Q & Q & & \\
\hline International Investment Position $^{6}$ & Q1 2010 & $\begin{array}{l}\text { May. } \\
2010\end{array}$ & Q & Q & Q & & \\
\hline
\end{tabular}

${ }^{1}$ Any reserve assets that are pledged or otherwise encumbered should be specified separately. Also, data should comprise short-term liabilities linked to a foreign currency but settled by other means as well as the notional values of financial derivatives to pay and to receive foreign currency, including those linked to a foreign currency but settled by other means.

${ }^{2}$ Both market-based and officially determined, including discount rates, money market rates, rates on treasury bills, notes and bonds.

${ }^{3}$ Foreign, domestic bank, and domestic nonbank financing.

${ }^{4}$ The general government consists of the central government (budgetary funds, extra budgetary funds, and social security funds) and state and local governments.

5 Including currency and maturity composition.

${ }^{6}$ Includes external gross financial assets and liabilitiy positions vis-à-vis nonresidents.

${ }^{7}$ Daily (D); weekly (W); monthly (M); quarterly (Q); annually (A); irregular (I); and not available (NA).

${ }^{8}$ Reflects the assessment provided in the data ROSC or the Substantive Update (published in July 2010, and based on the findings of the mission that took place during December 09-22, 2009) for the dataset corresponding to the variable in each row. The assessment indicates whether international standards concerning concepts and definitions, scope, classification/sectorization, and basis for recording are fully observed (O); largely observed (LO); largely not observed (LNO); not observed (NO); and not available (NA).

${ }^{9}$ Same as footnote 7, except referring to international standards concerning source data, statistical techniques, assessment and validation of source data, and revision studies. 


\section{INTERNATIONAL MONETARY FUND}

\section{IMF Executive Board Concludes 2010 Article IV Consultation with the Republic of Korea}

On August 25, 2010, the Executive Board of the International Monetary Fund (IMF) concluded the Article IV consultation with the Republic of Korea. ${ }^{1}$

\section{Background}

Growth has rebounded impressively since the recession in the second half of 2008 . Following the collapse in economic activity in the fourth quarter of 2008 (-16.8 percent quarter-on-quarter seasonally adjusted annualized rate (SAAR)), the subsequent recovery has solidified with GDP growth at 7.4 percent (q/q SAAR) in the first half of 2010. The rebound owes primarily to supportive macroeconomic and financial sector policies. Exchange rate flexibility, the normalization of international trade, and capital inflows have also supported the relatively quick recovery. Growth is projected at 6.1 percent in 2010 , led by fixed investment and restocking before easing to $4 \frac{1}{2}$ percent next year. Risks to the outlook are broadly balanced.

Despite the recovery and strong capital inflows, inflation pressures and asset valuations remain contained. There are no signs yet of inflation pressures and inflation expectations remain well anchored as reflected in consensus forecasts. However, both headline and core inflation have trended up in recent months to 2.6 and 1.7 percent, respectively, from 2.3 and 1.5, respectively, in March. With Korea and other Asian economies leading the global economic recovery, capital inflows have rebounded. Renewed investor risk appetite and ample liquidity in the advanced economies have amplified this trend. In

\footnotetext{
${ }^{1}$ Under Article IV of the IMF's Articles of Agreement, the IMF holds bilateral discussions with members, usually every year. A staff team visits the country, collects economic and financial information, and discusses with officials the country's economic developments and policies. On return to headquarters, the staff prepares a report, which forms the basis for discussion by the Executive Board. At the conclusion of the discussion, the Managing Director, as Chairman of the Board, summarizes the views of Executive Directors, and this summary is transmitted to the country's authorities. An explanation of any qualifiers used in summings up can be found here: http://www.imf.org/external/np/sec/misc/qualifiers.htm.
} 
Korea, capital inflows have mainly been concentrated in portfolio investments, boosting equity prices. Housing prices are above their lows in early 2009 , but the momentum in the housing market has slowed in recent months.

Korean banks entered the 2008 crisis well capitalized and with low nonperforming loans, although their reliance on wholesale funding proved to be a vulnerability. Since the crisis, banks have raised their average capital adequacy ratio (CAR) to 14.6 percent, 2 percentage points above pre-crisis levels. Moreover, nonperforming loan (NPL) ratios have remained low on average, partly due to significant write-offs, but NPLs remain high for savings banks exposed to ailing construction companies.

Exports have been buoyant, especially to China, but the rebound in imports associated with the recovery in domestic demand has led to a narrowing of the surplus relative to last year. Foreign exchange reserves have risen by close to US\$75 billion since their lows during the crisis, currently standing at US\$274 billion. The real effective exchange rate has appreciated by 22 percent since its weak point in March 2009, but still remains below pre-crisis levels.

Korea has embarked on exiting from the supportive macroeconomic and financial sector policies introduced during the crisis. The 2010 deficit is projected to decline to $11 / 2$ percent of GDP (excluding social security funds) following a deficit of 4.1 percent of GDP in 2009, primarily driven by the nonrenewal of most stimulus measures. This implies a negative fiscal impulse of close to 2 percent of GDP. Having kept the policy rate unchanged at 2 percent since February 2009, the Bank of Korea in July raised the policy rate by 25 basis points. However, monetary policy still remains highly accommodative. Most measures in support of small- and medium-sized enterprises (SMEs) are being gradually unwound, while many facilities in support of the financial sector remain in place, although utilization has been limited.

\section{Executive Board Assessment}

Executive Directors commended the Korean authorities for their swift and decisive policy response, which has contributed to an impressive economic recovery since early 2009. Growth is expected to be strong in 2010 , increasingly led by private sector demand, and the economy is likely already at, or close to, its potential level. The outlook is nevertheless subject to downside risks related to a global economic weakening and heightened global financial strains, especially in advanced economies.

Against this background, Directors agreed that a carefully calibrated exit from supportive macroeconomic policies is appropriate. This comprises a measured fiscal withdrawal in 2011, a gradual normalization of policy rates given the current accommodative monetary stance, and a further unwinding of support to the financial sector and SMEs. Directors also called for preserving exchange rate flexibility as a key element of the exit strategy. At the same time, it would be important that the authorities stand ready to adjust their policy stance in the event that downside risks to growth materialize.

Directors welcomed the plan to balance the central government budget (excluding social security funds) by 2013-14, in light of the rapidly aging population and the need to retain room for counter-cyclical policies. Directors saw scope for broadening the tax base and for raising social security contributions. A further formalization of the medium-term fiscal 
framework, including through the introduction of a binding fiscal rule, would provide an additional anchor for fiscal policy. Directors considered it prudent to monitor public enterprises' debt and to review their investment plans.

Directors agreed that overall price stability should remain the central bank's over-riding objective. Some Directors saw merit in broadening the monetary policy framework to allow for policy responses to emerging pressures in asset markets or the excessive buildup of leverage.

Directors underscored the need to better incorporate macro-financial linkages into the policymaking process. Most Directors noted that, while taking into account countryspecific circumstances, consideration could be given to further strengthening the coordination process among the relevant agencies charged with financial stability. Directors welcomed the authorities' pre-emptive steps to tighten prudential regulations, as well as their readiness to adopt new measures to upgrade the supervisory and regulatory frameworks as they emerge from international consensus. They looked forward to the forthcoming Financial Sector Assessment Program (FSAP) update.

Directors considered that strengthening domestic sources of growth would reduce Korea's vulnerability to economic downturns elsewhere in the world. They encouraged the authorities to introduce bolder reforms to raise productivity in the nontradable sector, including expediting a bank-led restructuring of troubled SMEs and opening up for competition in the service sector. Increased labor market flexibility and social protection would also help facilitate the rebalancing of the economy.

Public Information Notices (PINs) form part of the IMF's efforts to promote transparency of the IMF's views and analysis of economic developments and policies. With the consent of the country (or countries) concerned, PINs are issued after Executive Board discussions of Article IV consultations with member countries, of its surveillance of developments at the regional level, of post-program monitoring, and of ex post assessments of member countries with longer-term program engagements. PINs are also issued after Executive Board discussions of general policy matters, unless otherwise decided by the Executive Board in a particular case. The staff report (use the free Adobe Acrobat Reader to view this pdf file) for the 2010 Article IV Consultation with Korea is also available. 
Korea: Selected Economic Indicators, 2006-11

\begin{tabular}{|c|c|c|c|c|c|c|}
\hline & \multirow[b]{2}{*}{2006} & \multirow[b]{2}{*}{2007} & \multirow[b]{2}{*}{2008} & \multirow[b]{2}{*}{2009} & \multicolumn{2}{|c|}{ Projections } \\
\hline & & & & & 2010 & 2011 \\
\hline Real GDP (percent change) & 5.2 & 5.1 & 2.3 & 0.2 & 6.1 & 4.5 \\
\hline Total domestic demand & 4.9 & 4.5 & 1.4 & -3.2 & 6.4 & 3.3 \\
\hline Final domestic demand & 4.6 & 4.9 & 0.8 & 0.8 & 3.4 & 2.9 \\
\hline Consumption & 5.1 & 5.1 & 2.0 & 1.2 & 2.6 & 3.3 \\
\hline Gross fixed investment & 3.4 & 4.2 & -1.9 & -0.2 & 5.3 & 1.9 \\
\hline Stock building $1 /$ & 0.3 & -0.3 & 0.6 & -3.8 & 2.7 & 0.4 \\
\hline Net foreign balance $1 /$ & 0.3 & 0.7 & 1.1 & 3.1 & 0.2 & 1.5 \\
\hline Nominal GDP (in trillions of won) & 908.7 & 975.0 & $1,026.5$ & $1,063.1$ & $1,154.1$ & $1,249.7$ \\
\hline \multicolumn{7}{|l|}{ Saving and investment (in percent of GDP) } \\
\hline Gross national saving & 30.2 & 30.0 & 30.6 & 31.0 & 31.7 & 31.4 \\
\hline Gross domestic investment & 29.6 & 29.4 & 31.2 & 25.9 & 29.5 & 28.9 \\
\hline Current account balance & 0.6 & 0.6 & -0.6 & 5.1 & 2.2 & 2.5 \\
\hline \multicolumn{7}{|l|}{ Prices (percent change) } \\
\hline CPI inflation (end of period) & 2.1 & 3.6 & 4.1 & 2.8 & 3.0 & 3.5 \\
\hline Core inflation (average) & 1.8 & 2.3 & 4.3 & 3.6 & 2.3 & 2.5 \\
\hline GDP deflator & -0.1 & 2.1 & 2.9 & 3.4 & 2.3 & 3.6 \\
\hline Real effective exchange rate & 7.4 & 0.1 & -19.9 & -12.4 & $\ldots$ & $\ldots$ \\
\hline \multicolumn{7}{|l|}{ Trade (percent change) } \\
\hline Export volume & 13.2 & 10.4 & 6.8 & 0.0 & 14.7 & 9.3 \\
\hline Import volume & 10.5 & 9.0 & 0.9 & -7.9 & 16.7 & 7.9 \\
\hline Terms of trade & -6.6 & -2.5 & -14.3 & 8.9 & -2.9 & 0.4 \\
\hline \multicolumn{7}{|l|}{ Consolidated central government (in percent of GDP) } \\
\hline Revenue & 23.1 & 25.0 & 24.4 & 24.0 & 23.7 & 23.5 \\
\hline Expenditure & 21.3 & 21.5 & 23.3 & 25.7 & 22.8 & 22.0 \\
\hline Overall balance & 1.7 & 3.5 & 1.2 & -1.7 & 0.9 & 1.5 \\
\hline Excluding Social Security Funds & -1.2 & 0.4 & -1.5 & -4.1 & -1.4 & -0.8 \\
\hline \multicolumn{7}{|l|}{ Money and credit (end of period) } \\
\hline Overnight call rate $2 /$ & 4.6 & 5.0 & 2.9 & 2.0 & 2.0 & $\ldots$ \\
\hline Three-year AA- corporate bond yield 2/ & 5.3 & 6.8 & 7.7 & 5.5 & 4.8 & $\ldots$ \\
\hline M3 growth (y/y, in percent) $3 /$ & 10.5 & 10.0 & 9.1 & 9.4 & 9.2 & $\ldots$ \\
\hline \multicolumn{7}{|l|}{ Balance of payments (in billions of U.S. dollars) } \\
\hline Exports, f.o.b. & 331.8 & 379.0 & 432.9 & 373.6 & 459.9 & 510.2 \\
\hline Imports, f.o.b. & 303.9 & 350.9 & 427.3 & 317.5 & 409.6 & 446.5 \\
\hline Oil imports & 55.9 & 60.3 & 85.9 & 52.9 & 68.6 & 72.9 \\
\hline Current account balance & 5.4 & 5.9 & -5.8 & 42.7 & 22.4 & 27.4 \\
\hline Gross international reserves (end of period) $4 /$ & 238.9 & 262.1 & 201.1 & 269.9 & 280.3 & 294.0 \\
\hline In percent of short-term debt (residual maturity) 4/ & 172.5 & 130.8 & 105.3 & 138.2 & 144.0 & 152.2 \\
\hline \multicolumn{7}{|l|}{ External debt (in billions of U.S. dollars) } \\
\hline Total external debt (end of period) & 260.1 & 383.2 & 377.9 & 401.9 & 402.0 & 400.5 \\
\hline Of which: Short-term (end of period) & 113.7 & 160.2 & 149.9 & 150.0 & 149.1 & 147.7 \\
\hline Total external debt (in percent of GDP) & 27.3 & 36.5 & 40.5 & 48.3 & 40.0 & 36.8 \\
\hline Debt service ratio $5 /$ & 7.4 & 7.5 & 10.2 & 10.5 & 9.1 & 8.4 \\
\hline
\end{tabular}

Sources: Korean authorities; and IMF staff estimates and projections.

$1 /$ Contribution to GDP growth.

2/ Data for 2010 are as of August 2.

3/ Data for 2010 are as of May.

4/ Excluding gold.

5/ Debt service on medium- and long-term debt in percent of exports of goods and services. 


\section{Statement by Hi-Su Lee, Executive Director for Korea, Suk-Kwon Na, Senior Advisor to the Executive Director, and Ji-Sung Moon, Advisor to the Executive Director August 25, 2010}

1. The Korean economy, one of the economies leading the recovery from the financial turmoil, has recorded rapid economic growth along with relatively stable employment and price stability. The Korean authorities are now implementing a well-calibrated and gradual exit strategy, while aiming to achieve strong and sustainable long-term economic growth.

2. Our Korean authorities appreciate the staff's constructive policy dialogue and will give due consideration to the staff's recommendations. This paper, a pilot initiative as part of innovative reform of staff papers, is successful in streamlining the report and providing a summary of major issues with regard to the Korean economy.

\section{Economic Outlook and Risks}

3. A faster-than-projected recovery is expected. GDP growth rate in the first half of 2010 picked up to $7.6 \%$ y-o-y, recording the highest growth rate in the past decade and thus raising the Ministry of Strategy and Finance (MOSF)'s growth outlook in 2010 to 5.8\%, which is slightly lower than staff's outlook of $6.1 \%$. This recovery was underpinned by the timely and decisive policy response of the authorities, and supported by solid growth of private consumption and investment spurred by the strong rebound of exports. Employment is expected to pick up more rapidly than expected. Inflation is expected to remain well within the inflation target range, while the current account is likely to record a surplus of over USD 15 billion in 2010. Financial market conditions have also stabilized. The Korean stock market gained more than 70 percent in value, while the nominal exchange rate appreciated approximately 35 percent against the U.S dollar from their lows of March 2009. Foreign exchange reserves have risen to USD 286 billion as of end-July 2010, surpassing pre-crisis levels. Consumer confidence has rebounded and reached a seven-year high by end-2009, while business confidence has also strengthened.

4. Against the backdrop of this robust recovery, a calibrated exit from accommodative macroeconomic policies is being implemented in a very cautious manner. The fiscal deficit will be gradually reduced and will be eliminated between 2013 and 2014. Small and Medium Enterprise (SME)-support measures are being gradually unwound. Liquidity support injected into financial markets has been gradually reversed as well.

5. Being an open economy, however, Korea remains vulnerable to external shocks. Its large exposure to global trade and international capital markets always poses key risk to the Korean economy. Accordingly, despite its small exposure to southern Europe, our authorities have been closely monitoring and preparing for any negative spillovers from the European financial crisis. Any adverse spillovers from the impact of major economies' exit strategy as well as a possible increase of global commodity prices will receive due and vigilant attention. 


\section{Fiscal Soundness and Consolidation}

6. The recent European crisis demonstrates the importance of fiscal soundness. For ensuring fiscal soundness, the Korean government has developed the National Fiscal Management Plan (NFMP) and the National Debt Management Plan (NDMP), the objectives of which can be adjusted to accommodate economic and fiscal circumstances on a rolling basis. With fiscal stimulus being gradually reduced, the fiscal deficit, which rose to $4.1 \%$ of GDP during the crisis in 2009, is projected to drop to $2.7 \%$ in 2010 and will be eliminated between 2013 and 2014, while the public debt to GDP ratio will stabilize at mid-30 percent levels.

7. Fiscal soundness will greatly help secure appropriate policy ammunition against any future crises. To this end, the authorities will broaden the tax base by eliminating some tax deductions/exemptions and will enhance expenditure efficiency by curtailing excessive or overlapping expenditures. On the fiscal framework, the fiscal soundness management system will be improved by periodic analysis of fiscal risks and reorganization of the fiscal statistics infrastructure. The authorities are developing a new NFMP covering 2011-2015, which will specify detailed measures for medium-term fiscal consolidation. In this context, a fiscal rule recommended by staff will be introduced, if necessary.

8. The recent debt increase of public enterprises is not likely to create fiscal burden on the Korean economy. In the history of the Korean economy, public enterprises have contributed to its dramatic economic growth by undertaking large scale infrastructure investments. As of the end of 2009, public enterprises debt has increased by KRW 114 trillion from end-2005. However, their assets recorded an increase by KRW 137 trillion during the same period, 20\% higher than the debt increase. Given such large asset growth and continued net annual profit of KRW 3.3 trillion on average since 2005, the recent debt increase is not likely to create fiscal burden. Nevertheless, our authorities will closely monitor the development of public enterprises' debt levels, review their medium and long term investment plans, and prepare for tailored debt management plans.

\section{Monetary Policy Coordination and Objective}

9. Inflation has remained subdued despite the accommodative monetary policy. Core inflation has continued to remain below 2 percent since February 2010. Headline inflation, 2.6 percent in July 2010, remains comfortably within the inflation target of $3 \pm 1$ percent. Against this backdrop, the Monetary Policy Committee (MPC) had maintained the policy interest rate at 2 percent since February 2009. However, in July 2010, the MPC raised the policy rate to 2.25 percent, reflecting the recent economic recovery.

10. The MPC, as an independent policy-rates setter, determines the rate with comprehensive consideration of economic circumstances, price pressure, and financial market developments. The revision of the BOK Act in 1997 has served as the momentum to significantly strengthen the independence of the Committee. For example, the Governor of the Bank of Korea has been designated as the Chairman of the Committee. The Act ensured the guaranteed term of the Committee members and also improved the independence of 
budget and personnel affairs of the BOK. Given the need for continued policy coordination with the government, the BOK Act still entitled the MOSF (Vice Minister) to attend the MPC meeting and voice its view. Since January 2010, such attendance has resumed, after consultation with the MPC, to meet the need for policy coordination among authorities. It reflects the lessons from the crisis that cooperation between the government and central bank is critical to cope with crisis. Some advanced countries like UK and Japan are also implementing similar practice.

11. Price stability has still been the primary and sole objective of the BOK. In the wake of recent crisis, a revision to the BOK Act, making it pay attention to financial stability, is being discussed in the National Assembly. Including financial stability as the central bank's additional policy goal is still contentious. As we recall, during the Board meeting on "Central Banking Lessons from the Crisis" in June, it was highlighted that "assigning only one policy instrument- the policy interest rate- to more than one objective would confront monetary policy with sharp trade-offs and could well lead to a failure to achieve either objective". Since this is one of the highly controversial issues up until now, more careful and in-depth review will be made before a final decision is reached.

Safeguarding Financial Sector Stability

12. The two episodes of crisis experienced by Korea were mainly triggered by capital flow volatility. A huge capital inflow during the economic boom and rapid capital outflow in the subsequent downturn adversely affected the financial system and collapsed its economy. Korea's flexible exchange rate has thus far played the role of a shock absorber very well. But more needs to be done. Against this backdrop, our authorities introduced strengthened macro-prudential regulations in June 2010, such as limiting banks' foreign currency forward positions and tightening regulations for domestic foreign currency lending. This aims to address the banks' wholesale funding problem and to reduce currency and maturity mismatches. The design and the degree of regulations will be revisited later following the review of outcomes.

\section{Establishing the Financial System Stability Council (FSSC) was recommended by}

staff. In Korea, however, there are various policy coordination channels among relevant authorities and, in practice, policy coordination and information sharing among them including BOK has been very successful, as was evidenced by its fast recovery from the crisis. Moreover, Financial Services Commission (FSC) is very similar with the FSSC in many aspects. All the relevant bodies (MOSF, BOK, Financial Supervisory Service (FSS), and Korea Deposit Insurance Corporation (KDIC)) participate in the FSC as a commissioner, and each body has analyzed systemic risks from its own perspective. As a result, Korean authorities' policies have been well-designed and successfully implemented in a coordinated manner. More consideration to country-specific circumstance could have enhanced the credibility of the staff's recommendations.

14. A cautious approach for so-called "Mega bank" is appropriate. Currently, regulating the size of individual financial institution is being discussed by some advanced countries. Country-specific circumstance, such as differences in terms of size of financial agencies, the development stage of financial industry, and supervisory and regulation system, 
should be carefully considered. Going forward, the Korean authorities will take a balanced and cautious approach along with sufficient comparative analysis, with the main focus being placed on enhancing the financial industry competitiveness as well as preventing systemic risks.

\section{Structural Reform}

15. Productivity-driven and balanced growth will be pursued. The policy focus is shifting from overcoming crisis to preparing for the next challenge. "New Policy Goals beyond the Crisis" was recently announced in this context. This elaborates mid- to long-term comprehensive development strategies to achieve strong and sustainable long term growth. To this end, revitalizing and increasing the competition in the non-tradable sector including the service industry will be prioritized. In May 2009, our authorities launched a major initiative to develop the service industry and selected nine service sectors based on their growth potential and job creation as well as value added and trade deficit reduction. Up to date, this initiative has been continuously implemented.

16. Continued increase of household debt, in particular of mortgage debt, has seized our authorities' attention. Household debt remains higher than the average level of OECD countries. Nevertheless, the majority of debt belongs to high-income households with a large amount of financial assets. The delinquency rate on household loans remains very low, recording $0.54 \%$ as of March 2010. Given the sufficient accumulation of provisions for bad debts, banks remain resilient against shocks. However, as the rapid rise in household debt and de-leveraging may dampen the economy's growth potential, our authorities will remain vigilant. Macro and micro prudential regulations such as Loan-to-Deposit ratio, Loan to Value (LTV), and Debt to Income (DTI) will be continued. In addition, financial assistance measures including micro-finance projects will reduce the financial burden of low income families.

17. Unlike the household, SMEs have sound balance sheet. Their financial soundness was greatly improved since the financial crisis in 1997. The debt to equity ratio decreased from $418 \%$ in 1997 to $137 \%$ in 2009 , while equity to asset ratio rose from $19 \%$ in 1997 to $42 \%$ in 2009 . Comparison with major economies also shows that financial soundness indices of Korean SMEs are similar to or better than those of companies in major economies. However, bank-led restructuring of troubled SMEs will be expedited, and the process of restructuring will be continuously monitored. Most SMEs-support measures are being normalized. The financial support measures, which are being maintained to sustain market confidence and establish a safety net, will also be gradually unwound with due consideration to market conditions.

\section{Improving the labor markets flexibility has been one of the key priorities, the} importance of which we cannot over-emphasize. To make labor markets more flexible, employment protection for regular workers will be reduced while social protection for non regular workers will be expanded. A great deal of efforts have been made to enhance the flexibility of wages and working hours, such as creating jobs with reduced working hours as well as expanding the Wage Peak. At the same time, the social safety net will be expanded to 
facilitate employment stability, by enriching job training, upgrading employment support service, and expanding coverage of employment insurance.

19. The rapidly ageing population is one of the key challenges confronting Korea. It has the lowest fertility rate among OECD member countries, which stands at 1.15 children per woman in 2009. Its population over age of 65 is projected to increase from $11 \%$ in 2010 to $38.2 \%$ in 2050. In light of this, a five-year "Master Plan preparing for Ageing Society (2011-2015)" is being envisaged as a comprehensive response. This Plan will focus on boosting fertility rate by creating "work and family friendly" environment. Measures supporting employment and turnover of older population will be strengthened, and promoting public awareness on the importance of higher fertility rate will be enhanced.

\section{Conclusion}

20. Finally, our Korean authorities wish to express their utmost appreciation to the Fund and its staff for their policy advices in addressing the risks facing the country. They also extend their deepest gratitude to the mission chief and his team, for their hard work as well as frank advices in supporting the Korean economy. 